NBER WORKING PAPER SERIES

\title{
DOES THE FORMAT OF A \\ FINANCIAL AID PROGRAM MATTER? \\ THE EFFECT OF STATE IN-KIND TUITION SUBSIDIES
}

\author{
Bridget Terry Long \\ Working Paper 9720 \\ http://www.nber.org/papers/w9720 \\ NATIONAL BUREAU OF ECONOMIC RESEARCH \\ 1050 Massachusetts Avenue \\ Cambridge, MA 02138
}

May 2003

The author gratefully acknowledges invaluable comments from Caroline Hoxby, Larry Katz, Claudia Goldin, Richard Murnane, and members of the Harvard University Department of Economics Labor Seminar. Early work on this project was supported by a grant from the American Educational Research Association which receives funds for its "AERA Grants Program" from the National Center for Education Statistics, the Office of Educational Research and Improvement (U.S. Department of Education), and the National Science Foundation under NSF Grant \#RED-9452861. Opinions reflect those of the author and do no necessarily reflect those of the granting agencies. Send comments to longbr@gse.harvard.edu. The views expressed herein are those of the authors and not necessarily those of the National Bureau of Economic Research.

(C)2003 by Bridget Terry Long. All rights reserved. Short sections of text not to exceed two paragraphs, may be quoted without explicit permission provided that full credit including (C) notice, is given to the source. 
Does the Format of a Financial Aid Program Matter? The Effect of

State In-Kind Tuition Subsidies

Bridget Terry Long

NBER Working Paper No. 9720

May 2003

JEL No. I2, H7

\begin{abstract}
Does the format of a financial aid program influence how it affects college decisions? This paper examines this question by focusing on state appropriations to public postsecondary institutions. While these funds subsidize tuition costs for in-state students, the in-kind format of the aid and resulting price gap between public and private colleges could also affect choices between colleges. The paper analyzes this possible effect utilizing a conditional logistic choice model, which exploits extensive match-specific information between individuals and nearly 2,700 colleges. Using estimates of how price, quality, and distance influence college decisions, I examine the impact of several dissimilar state subsidy regimes and simulate how decisions would change if the aid were awarded in other ways. The results suggest that the level and distribution pattern of state subsidies strongly influence decisions. When in-kind subsidies are large, students appear to choose public colleges even if the gap in resources between public and private options is substantial. If the aid were instead distributed as a credit applicable to any in-state college, up to 29 percent more students would prefer to attend private four-year colleges. The results also suggest that the in-kind subsidies create incentives for students to favor public four-year colleges over two-year institutions.
\end{abstract}

\author{
Bridget Terry Long \\ Graduate School of Education \\ Harvard University \\ Gutman Library 465 \\ Appian Way \\ Cambridge, MA 02138 \\ and NBER \\ longbr@gse.harvard.edu
}




\section{SECTION I: INTRODUCTION}

State appropriations to public colleges form the most significant higher education aid policy in the United States. During the 2002-03 school year, contributions by state governments totaled $\$ 63.6$ billion, nearly four times the amount of grant aid administered by the federal government (Palmer, 2003). These state subsidies constitute nearly two-fifths of the total revenue received by public colleges while, in contrast, private institutions rely primarily on tuition income (nearly half of their total revenues). This difference in revenue source is apparent from the average tuition costs of colleges in each sector. During 2002-03, four-year private colleges charged a mean list price of $\$ 18,273$ while public four-year colleges charged only $\$ 4,081$ for in-state students (College Board, 2002). After accounting for the fraction of the disparity attributable to differences in expenditures, the price gap remains large and could affect the sector and quality of colleges students choose. ${ }^{1}$ Therefore, while state subsidies may reduce price barriers to postsecondary education by allowing public colleges to charge in-state students a discounted price, they may also affect choices between colleges. ${ }^{2}$ This paper examines how the in-kind format of a financial aid program influences the effect it has on college decisions about enrollment and choice.

Governments have implemented several types of financial aid programs to reduce college price barriers and lower the cost of capital for liquidity-constrained individuals. Fungible aid, such as the federal Pell Grants, may be applied to any school and thereby extends the entire budget constraint of a student. Quite the opposite, in-kind aid is linked to specific colleges and extends the budget constraint only for particular choices. State tuition subsidies thereby disturb tradeoffs between colleges since tuition costs for schools in the unsubsidized private sector are expensive relative to state-supported public institutions. Because colleges vary in the resources they offer, this price distortion could affect college investment decisions in nontrivial ways. There may be important quality differences between the institutions in a student's opportunity set, and the price gap created by the in-kind subsidies could

\footnotetext{
${ }^{1}$ During the 1991-92 school year, the focus of this study, private four-year colleges spent $\$ 1,258$ more per student on instruction, academic support, and student services than public four-year colleges. Privates spent $\$ 4,245$ more in terms of total educational and general expenditures. Source: Calculated by the author using the 1991-92 IPEDS. ${ }^{2}$ Given budget constraints, state aid allows for reductions in other sources of revenue at public colleges, most notably tuition. The correlation between the mean tuition cost of four-year, public colleges and the mean amount of state appropriations received by such schools was -0.7 from 1977 to 1997 (NCES data). In practice, schools are generally discouraged by the state from increasing the tuition above a certain percentage each year unless state appropriations are reduced thereby implicitly linking the subsidy and tuition level.
} 
persuade individuals to choose schools that devote fewer resources, such as expenditures, faculty, or peers, to the production of education. ${ }^{3}$ As a result, this particular form of aid could cause individuals to invest in less quality-adjusted human capital than they would if the grants were fungible and perhaps less than they would in the absence of aid. Peltzman (1973) concludes that in-kind tuition subsidies therefore could reduce the aggregate consumption of higher education, contrary to the aims of an aid policy.

The price distortion may also affect the incentives of public institutions. If the subsidies enable public colleges to avoid competing directly with private institutions, then they will have less incentive to maximize educational quality while minimizing costs. In fact, if private colleges are more efficient, inducing students to attend the subsidized, public colleges would result in a welfare cost (Sonstelie, 1982). Recently, several states, most notably Colorado, have begun to consider reforms that would reduce state operational subsidies in favor of college vouchers for students with the hope that such changes would force public colleges to be more responsive to students' needs.

Many also question whether aid irrespective of income is the best method to provide support since the subsidies may primarily help inframarginal students who are without need even when facing unsubsidized costs. Moreover, the method of financing the aid may cause unintended redistribution. State appropriations per student vary greatly across colleges, and therefore, attendance patterns have a substantial impact on the amount of aid students of each income level receive. Using California data, Hansen and Weisbrod (1969a and 1969b) found that college attendance at highly-subsidized schools is primarily a middle- to upper-income activity. Because all income groups pay taxes, they argue that state subsidies could therefore be regressive depending on the progressivity of state sales, income, and property taxes. These findings have sparked an ongoing debate about the incidence of state tuition subsidies.

This paper focuses on the effect of in-kind state tuition subsidies on several aspects of the enrollment decision. First, how does the aid affect whether individuals choose to attend college and which school they choose? Second, do in-kind subsidies induce students to choose lower-quality colleges than they would otherwise as asserted by Peltzman? That is, does the practice of subsidizing

\footnotetext{
${ }^{3}$ Since students are considered inputs as wells as outputs in educational production, students with lower test scores
} 
public colleges negatively distort human capital investment decisions? Finally, the paper examines the counterfactual proposition of how student decisions would change if the state aid were no longer in-kind and instead were given as direct grants to students that could be applied towards the tuition costs of any in-state college. This simulation provides a sense of the proportion of students' decisions that are affected by the in-kind nature of the aid.

To assess the impact of tuition subsidies on college investments, this paper estimates a model of college choice developed in Long (forthcoming). It is designed to take advantage of important matchspecific information between students and potential colleges. Unlike previous work that has had to rely upon state means or greatly simplified the college decision, I estimate a conditional logistic model in which each individual's match with 2,669 potential colleges is examined. Tuition costs are individualspecific based on state of residence net an expected Pell Grant. Variables also measure the similarity of the student to prospective college peers and the distance of the college from the student. Finally, the model includes several variables to measure the educational resources available to students, including peer and faculty quality and expenditures. While this model estimates the probability of attending each college in the choice set, conditional on college enrollment, a second model estimates whether the student would enroll in college at all. ${ }^{4}$ Students who do not attend college in one state might decide to do so in another given a different set of alternatives and prices. To account for this, I estimate the likelihood of attendance using a basic logistic model with controls for background, local labor market conditions, and the characteristics of the college most-likely to be attended.

The parameters of this two-step college choice model are identified off of the considerable variation in states' in-kind subsidy programs. For example, during the 1991-92 school year (the focus of this study), state appropriations per public college student ranged from $\$ 10,296$ in Alaska to $\$ 3,021$ per student in Vermont. Likewise, the subsidized tuition prices of public four-year colleges differed by state: that year California charged only $\$ 1,448$ on average while Vermont charged $\$ 4,625 .^{5}$ However, distinctions between state programs involve not just the average amount of the subsidy but how the

could provide less-favorable peer effects than higher-achieving students.

${ }^{4}$ While ordinarily a nested logit model would be used to estimate the two decisions simultaneously, the conditional logit model is too complex for a simple application of the theory, and therefore, a two-step method is applied. 
subsidies are distributed among schools with different degrees of selectivity (student body aptitude), expenditure levels, and levels (two-year versus four-year). Several possible subsidy regimes exist. At one extreme, a state could offer highly-selective, subsidized public colleges. For example, California supports UC Berkeley, which boasts a median student body SAT of 1250 and 1991-92 student expenditures over $\$ 12,000$ per student (see Figure 1). In contrast, a state may only support schools with average-ability students. For example, Massachusetts does not offer public colleges with a student body SAT median above 950 or student expenditures above \$5,900 per student (see Figure 2). ${ }^{6}$ Rather than mask this variation by using the average characteristics of the colleges in a state as has been done in the previous literature, this study attempts to account for the substantial heterogeneity in the market of higher education and test how the distribution of colleges could affect enrollment decisions.

Because populations vary by region, linking state aid to the investments made by each state's students would be misleading. However, estimates from this college choice model allow me to assess the impact of state in-kind support by simulating the effect of different subsidy regimes on a common group of students. To test Peltzman's hypothesis, the paper demonstrates what would happen if individuals were presented with the level and distribution of subsidies they would face in several, dissimilar states. While there may potentially be endogeneity between state policies and their populations, states with similar demographics pursue vastly different policies providing the opportunity to do such a comparison. Further simulations explore how decisions would change if states used their current appropriations to fund a college voucher. Public college prices are adjusted upward to account for the loss of state appropriations, and in-state tuition amounts are reduced by the value of the state voucher. The results suggest that the level and distribution of state subsidies strongly influence college investment decisions, and Peltzman's hypothesis is valid. When in-kind subsidies are medium to large, students appear to choose public colleges even if the gap in resources between public and private options is substantial. If states instead awarded individuals with a voucher that could be applied to any in-state school, the number that would prefer to attend private four-year colleges increases by 20 to 29 percent.

\footnotetext{
${ }^{5}$ Digest of Education Statistics (1993). Per student figures are in terms of fulltime equivalent (FTE) enrollments.

${ }^{6}$ In 1992 dollars. The college selectivity measures are from Barron's Educational Guides (1997). Student expenditures are defined as funds for instruction, academic support, and student services.
} 


\section{SECTION II: LITERATURE REVIEW}

\section{In-kind Financial Aid and College Demand}

Several justifications for the state support of higher education are rooted in economic theory. First, capital markets for financing higher education are imperfect, and liquidity-constrained individuals may not be able to secure the funds necessary to make their optimal investments. State subsidies address this market imperfection by providing a long-term loan: individuals benefit as students and repay the state in taxes over the rest of their lives. Furthermore, state aid could induce society-at-large to invest at a more optimal level. The private investment considerations of an individual ignore the positive externalities education produces for society and may lead students to underinvest in education. A policy that increases individual investments, and the resulting education externalities, could therefore move the economy toward a social optimum. Aid to educational institutions may also be justified if colleges and universities provide beneficial public goods such as products or information for the state. Finally, the inkind format of the aid and the fact that public institutions are the providers of the product reduces the likelihood that the service rendered will be inadequate or below expectations.

While economic theory suggests that state subsidies could help remedy market imperfections, inkind aid could also generate distortions. Peltzman (1973) suggests that in-kind subsidies may discourage students from investing in education beyond what is offered at the subsidized schools. Of particular concern are students who, in the absence of subsidies, would choose to invest in slightly more education than that offered by public colleges. Figure 3 illustrates the logic. Individuals have a budget constraint that relates the level of investment in higher education to the consumption of other goods. Private options sit on the curve (which has been drawn as linear for simplicity). However, due to the state subsidy, the price of a public college, for any given level of educational expenditures, is lower than that of a private school. Public options allow students to invest in more human capital than is dictated by their original budget constraint and still consume the same amount of other goods. Therefore, an individual's budget constraint becomes "kinked" at the public options. Individuals will tend to gravitate towards the public options due to the accompanying increase in the consumption of other goods. If a 
sufficient number of students adjust their investments downward in terms of expenditures and quality, then aggregate educational investment could fall (Peltzman, 1973).

The insurance properties of state aid generate further concerns about college demand. Since state aid is funded by income taxes, individuals are not held fully responsible for the costs of higher education if they do not realize a large educational return. Therefore, adverse selection may be a problem if the subsidies encourage college attendance among individuals who know they have a low probability of earning enough later in life to fully "repay" the state for its expenditure on their education. Furthermore, a moral hazard problem may exist if individuals invest in a great deal of education but elect never to work and therefore do not "repay" the state at all.

\section{Estimates of the Effect of Price on Student Demand}

Economists have utilized the demand framework to study how changes in the price of higher education have affected individuals' choices about college. College demand will depend upon the cost of education, the prices of alternatives, and the preferences of the individual subject to a budget constraint. Therefore, investment in higher education should be negatively related to tuition costs, and public tuition subsidies should increase the probability of enrollment.

Most studies on the effect of cost relate college investment to tuition and/or aid levels using variation across time or geographic region. Campbell and Siegel (1967) were likely the first to do this when examining the demand for higher education from 1919 to 1964. Building upon this approach, Hopkins (1974) exploits 1963 state-level variation with controls for state education and income levels and finds a demand elasticity of -0.10 with respect to net public tuition (mean state charges minus mean state scholarship aid). In other words, the discouragement effect of a $\$ 1,000$ increase (1992 dollars) in public tuition in 1963 would have caused a ten percent drop in attendance. ${ }^{7}$ Hopkins also documents a substitution effect: he finds that private college enrollments increase when public tuitions rise thereby highlighting the importance of relative costs in students' decisions between colleges in different sectors.

\footnotetext{
${ }^{7}$ Figures are reported in 1992 dollars so as to make them comparable to the results of this study. A $\$ 1,000$ change is equivalent to a $\$ 222$ increase in 1963 dollars or doubling the mean tuition cost of public colleges at that time. Source: Statistical Abstract of the U.S.
} 
Hopkins concludes that policies that lower public tuition levels could cause some inframarginal students who would have otherwise chosen a private college to reallocate themselves to the public sector.

Manski and Wise (1983) try to more precisely approximate the college outlook of a student using a multinominal logistic model of school choice. They define the opportunity set of a student by exploiting information about the student's application set and nearest community college and find tuition costs to have the expected negative effect. Similar to the majority of studies reviewed by Leslie and Brinkman (1988), Manski and Wise predict that a $\$ 1,000$ change in price would result in a three- to fivepercentage point change in college attendance. The magnitude of the effect is found to be approximately equal for changes in scholarship aid.

Kane (1995) provides more recent estimates of the importance of public tuition levels by examining both between-state differences and within-state changes in public tuition prices during the late 1970s and 1980s. Using several data sources (the High School and Beyond, National Longitudinal Survey of Youth, and October Current Population Survey), he finds a response of -0.10 to -0.20 for a $\$ 1,000$ increase (1992 dollars) in public two-year tuition. This translates into an elasticity of demand of 0.20. Kane also find that low-income students and those attending two-year colleges appear to be most affected by price changes. McPherson and Schapiro (1991) provide further support for the notion that low-income students are more sensitive to price. They estimate that a $\$ 150$ increase (1994 dollars) in net price over time led to a 1.6-percent decline in enrollment among poorer students (an elasticity of -0.41). McPherson and Schapiro do not find evidence that increases in net cost inhibit enrollment for more affluent students.

While these studies have established the importance of price in college decisions, Ganderton (1992) provides the first direct test of the Peltzman hypothesis. Ganderton examines the effect of state subsidies on students' college choices particularly focusing on school quality. Defining college quality using the mean student body SAT scores of a school, he finds that students choose a substantially less selective public college than they would have chosen in the private sector thereby providing suggestive support of Peltzman's hypothesis. 


\section{Concerns about Aggregation}

While college demand studies based on cross-sectional variation in state-level tuition data have been informative of the responses of students to college price and aid, the results are primarily identified by fixed differences between states. These estimates could therefore be misleading because it is difficult to distinguish the impact of tuition from any other characteristic of the state that has remained constant over time. As Kane (1995) and Rouse (1994) caution within their own work, interpreting state variation as a natural experiment for tuition changes has the problem that omitted state factors may be correlated with enrollment, subsidy level, and tuition. For example, if unobserved state preferences for higher education cause a state to provide larger tuition subsidies, the unobserved preferences could be negatively correlated with the mean tuition level of the state. The resulting parameter on tuition would be biased downward. This would suggest that the relationship between enrollment and tuition cost has been underestimated using state cross-sectional data. However, state income per capita may be positively correlated with tuition levels. This would result in the relationship between enrollment and price being exaggerated in estimation.

Another weakness of cross-sectional data at the state level is that it masks much of the heterogeneity in the market of higher education. While state subsidy and tuition levels vary significantly by state, most of the variation exists at a finer level. Tuition levels and subsidy amounts vary greatly among different levels of schools within a state. Public universities typically receive the largest subsidies, nearly the double the subsidy of public two-year colleges and on average ten percent more than that of public four-year colleges. Tuition levels differ in a similar manner by type of school with universities costing the most and two-year colleges the least. These differences also exist between fouryear, public colleges and universities. In California, for example, each University of California branch campus receives at least two and a half times the amount of state appropriations of a California State University site. In 1991-92, UC Davis received state appropriations that amounted to $\$ 11,536$ per fulltime equivalent (FTE) student while CSU Fullerton only received \$2,962 per FTE student. Likewise, tuition costs vary. That year UC Davis charged $\$ 2,980$ while CSU Fullerton cost only $\$ 1,480{ }^{8}$ Cost is

\footnotetext{
${ }^{8}$ Calculated by the author using the 1991-92 Integrated Postsecondary Education Data System (IPEDS).
} 
not the only variation that state-aggregation would mask. State variation in the number and quality of schools available to students is also substantial. States like California and Pennsylvania offer over thirty public, four-year institutions while states like Michigan and Virginia offer only fifteen. In terms of student body aptitude, a proxy for peer resources at the school, only Virginia and California offer public institutions rated as the most selective. ${ }^{9}$

Using state means masks much of the variation in cost, subsidies, and quality that could more clearly influence enrollment. For example, an above-average student in Massachusetts would have a very different opportunity set than one from California (review Figures 1 and 2). While each student would face similar costs for any private college in the country (except for traveling costs), the resident of California would have cheap public colleges available to her that provide substantial educational resources and peers of high-ability. If the student chose a public college in California rather than Massachusetts because it more closely matched his characteristics, there would be no way to distinguish in the data why. In fact, in a case like this, if the mean tuition levels in the state in which a college was not chosen were lower, it would appear that higher tuition costs increase the likelihood of attendance although unobserved school differences are really the motivating factor. Because ignoring the distribution of resources to different types, levels, and qualities of schools within a state could bias estimation of the parameters of college decisions, college heterogeneity is a major source of identification problems in determining the effect of tuition price and state subsidies. This study will avoid these problems using a framework designed to account for this variation.

\section{SECTION III: FRAMEWORK AND MODEL}

This section explains how this study accounts for heterogeneity in the college market using a conditional logistic choice model and a basic logistic enrollment model as developed in Long (forthcoming). Remaining concerns about the possible endogeneity of subsidy levels and an explanation of the data used are also discussed.

\footnotetext{
${ }^{9}$ Since students are considered inputs as wells as outputs in educational production, students with lower test scores could provide less-favorable peer effects than higher-achieving students.
} 


\section{Theoretical Framework}

Assume an individual has J colleges from which to choose. Each school, j, can be characterized by a vector $\mathrm{Y}$ which is composed of measures of college price and resources:

$$
\mathrm{Y}_{\mathrm{j}}=\left\{\mathrm{P}_{\mathrm{j}}, \mathrm{EX}_{\mathrm{j}}, \mathrm{SB}_{\mathrm{j}}\right\}
$$

where $\mathrm{P}_{\mathrm{j}}$ is the tuition price of school $j$. School resources are divided into two parts: expenditures (including faculty resources), denoted by $\mathrm{EX}_{\mathrm{j}}$, and peers, measured by student body aptitude, $\mathrm{SB}_{\mathrm{j}}$. In this way, each college can be viewed as a package containing resources for a given price. From these characteristics, an individual can infer how much value-added each school will produce for his human capital and consider the consumption goods the college offers. ${ }^{10}$

A vector X contains the individual's attributes such as high school performance, family income, and residence, which might affect his demand for education and his opportunity set. For example, his prior performance and ability will affect his likelihood of being accepted by a highly-selective college as opposed to a junior college. Let the value of the $\mathrm{j}^{\text {th }}$ college to the $\mathrm{i}^{\text {th }}$ decision maker be given by $U\left(\mathrm{Y}_{\mathrm{j}}\right.$, $\mathrm{X}_{\mathrm{i}}$ ). This value may partly depend on an interaction of the individual's characteristics with those of the school. For example, the distance of college $j$ for person $i$ is determined by the residence of the student relative to the location of the school. Additionally, a discount for college $j$ (e.g. a state tuition subsidy) may depend on the residence of the individual. Utility may have random elements so that all individuals with $\mathrm{X}_{\mathrm{i}}$ are not assumed have the same tastes:

$$
\mathrm{U}\left(\mathrm{Y}_{\mathrm{j}}, \mathrm{X}_{\mathrm{i}}\right)=\overline{\mathrm{U}}\left(\mathrm{Y}_{\mathrm{j}}, \mathrm{X}_{\mathrm{i}}\right)+\varepsilon_{\mathrm{ij}}
$$

That is, there are random deviations from the mean valuation Ū. If we assume that the non-random part of utility is a linear function of individual and college characteristics we get:

$$
\mathrm{U}\left(\mathrm{Y}_{\mathrm{j}}, \mathrm{X}_{\mathrm{i}}\right)=\mathrm{Z}_{\mathrm{ij} 1} \beta_{1}+\mathrm{Z}_{\mathrm{ij} 2} \beta_{2}+\mathrm{Z}_{\mathrm{ij} 3} \beta_{3}+\ldots+\mathrm{Z}_{\mathrm{ijk}} \beta_{\mathrm{k}}+\varepsilon_{\mathrm{ij}}
$$

\footnotetext{
${ }^{10}$ These two components of human capital accumulation, production and consumption, are an implication of the Becker and Rosen models of human capital. They are denoted as an institution's quality in this study.
} 
where $\beta$ is a vector of parameters, $Z_{\mathrm{ij}}$ are the variables that affect utility, and $\mathrm{k}$ is the total number of variables. $\mathrm{Z}$ may include variables that describe the elements of $\mathrm{Y}$ (i.e. $\mathrm{EX}_{\mathrm{j}}$ and $\mathrm{SB}_{\mathrm{j}}$ ), interact $\mathrm{Y}$ and $\mathrm{X}$ to form match-specific measures (i.e. $\mathrm{D}_{\mathrm{ij}}$ ), or dummy variables.

Individuals compare the potential returns to attending different colleges along with the option of not enrolling and entering the labor market directly. The college decision is therefore made up of two simultaneous choices. The individual must determine his best college option and concurrently decide whether to attend college at all. The individual chooses the option that maximizes his lifetime utility subject to his budget constraint as shown in (4).

$$
\text { choose } \mathrm{Y}_{\mathrm{k}} \text { iff } \mathrm{U}\left(\mathrm{Y}_{\mathrm{k}}, \mathrm{X}_{\mathrm{i}}\right) \geq \mathrm{U}\left(\mathrm{Y}_{\mathrm{j}}, \mathrm{X}_{\mathrm{i}}\right) \quad \forall \mathrm{k} \neq \mathrm{j} \text { with } \mathrm{P}_{\mathrm{ik}} \leq \mathrm{I}_{\mathrm{i}}
$$

where $I_{i}$ is the budget constraint and is related to income.

\section{The College Choice Model}

The above framework emphasizes several points that must be addressed in estimating how individuals choose between colleges conditional on enrollment. ${ }^{11}$ First, there is substantial heterogeneity among colleges that must be adequately characterized using institutional information on each school's tuition price, expenditures, and student body characteristics. Second, match-specific information is an important part of the model since colleges treat students differently depending upon residence. Furthermore, a particular college may not suit all students well, and this will depend on how the student's characteristics compare with those of the college's student body. Finally, to understand how students make decisions the framework needs to adequately capture the full opportunity set of individuals so that tradeoffs between the opportunity chosen and the alternatives not taken can be explored. This requires characterization of the nearly 2,700 colleges a student could attend. Therefore, unlike ordinary regression analysis, the model must be equipped to handle multiple alternatives.

\footnotetext{
${ }^{11}$ The group that did not attend college enters the analysis in a separate model. This is due to several reasons. First, describing the "not attend" option as an alternative with zero tuition cost, zero median test scores, and a distance of zero would bias parameter estimates. Since some individuals would choose not to attend (the option with no cost), the negative effect of tuition price on college choice would be exaggerated. In addition, the decision of whether to attend college is most likely nonlinear relative to choosing between different schools. Therefore, estimates of the
} 
The conditional logistic regression model is well-suited for this framework since it both allows for multiple alternatives and can be used to exploit match-specific information. Also known as McFadden's choice model (1973), the conditional logit has been used to study choice behavior with such applications as choice of travel mode and occupation, but computational limitations has not until now allowed its application to college choice. ${ }^{12}$ While the form of the likelihood function is similar to that of the multinomial logistic regression, the variables are choice-specific attributes rather than individualspecific characteristics. $^{13}$

For the conditional logistic model, the data are organized as pair-wise combinations of each student $i$ with each school $j$ so that there are a total of $i \times j$ observations. This allows for match-specific variables that interact information about the student with that of the college. Using these combinations, the conditional logit model is made up of $j$ equations for each individual $i$, with each equation describing one of the alternatives. The dependent variable, signifying the choice of the individual, equals one for the alternative that was chosen. The conditional logit model then calculates the probability of enrollment at each of the colleges in the stratum (i.e. it considers the probability of a person attending any one of the available schools). It does this by computing the likelihood of enrollment at each school relative to all alternatives so that the probabilities sum to one for each individual (or within one stratum). Under the assumption that the $\varepsilon_{\mathrm{ij}}$ 's are independent and identically distributed with the extreme value distribution, we get the conditional logit functional form:

$$
\begin{aligned}
& \operatorname{Pr}\left(E_{i j}\right)=e^{Z i j \beta} /\left(e^{Z i 1 \beta}+e^{Z i 2 \beta}+\ldots+e^{Z i j \beta}\right) \\
& \text { where } Z_{i j} \beta=\beta_{1} P_{i j}+\beta_{2} E X_{j}+\beta_{3} S B_{j}+\beta_{4} D_{i j}+\ldots+\varepsilon_{i}
\end{aligned}
$$

\footnotetext{
model including the "no college" option are unlikely to accurately describe both the college choice and the decision of whether to attend.

${ }^{12}$ Manski and Wise (1983) acknowledge the need to account for the many alternatives available to a prospective individual and outline the use of the conditional logit. However, limitations in computing power forced them to use a multinomial logit to analyze the decisions of individuals in the NLS72.

${ }^{13}$ If the independent variables were instead attributes of the individuals rather than alternatives, then the models would be the same. However, the multinomial logit model forces one to aggregate information about choices and enter them in a restrictive manner. The use of the conditional logit is therefore preferable for analyzing differences in states in-kind subsidy regimes.
} 
The probability of individual $i$ attending college $j, \operatorname{Pr}\left(\mathrm{E}_{\mathrm{ij}}\right)$, will be a function of the variables that define $\mathrm{Z}_{\mathrm{ij}}$ including elements that describe the school and individual characteristics. The format allows for maximum likelihood estimates of $\beta$, and the probability of any particular choice can be calculated using the conditional logit specification displayed in (5).

Since the likelihood of attendance at each college is calculated relative to the alternatives within each stratum, there must be variation within the strata for estimation purposes. For this reason, student characteristics cannot be included independently in the estimation. ${ }^{14}$ The estimation, therefore, does not identify the causal effect of a student's attributes on enrollment. Instead, the estimates indicate how school characteristics affect the likelihood of an individual enrolling at a school. Dummy variables are used to understand how reactions vary for different types of students. For instance, a low-income person may have a high cost of capital so that small price increases could greatly affect the probability of enrollment. To examine the effect of price and distance on low-income students, I interact these variables with a low-income dummy variable. Likewise, a high-ability individual may be influenced differently by school characteristics. If ability and school quality are assumed to be complements in the production of education, higher-ability students could expect to realize greater gains from schools with more resources. School expenditures could therefore be more important in their decisions of whether to choose a college, and the variable is interacted with a dummy variable for high ability.

If the Independence of Irrelevant Alternatives (IIA) condition is met, the estimates will be consistent even if the decision to attend college at all is endogenous. Possible endogeneity in the choice set develops from the fact that colleges available to a student will depend upon the previous decision of where to apply. This application decision is based upon a student's ranking of the colleges, and therefore, the opportunity set that a student will ultimately face is partly endogenous. However, as long as students apply to schools that they determine to be most preferred, estimation will retain good statistical properties due to the IIA property. ${ }^{15}$

\footnotetext{
${ }^{14}$ The $j$ equations within a stratum are not independent, and a person's gender, for example, would difference out of all the equations within one stratum since each contains data on only one individual. Therefore, unlike the multinomial regression model, non-college alternatives such as local labor market conditions can not be included within the model since they are individual-specific.

${ }^{15}$ See Manski and Wise (1983) for further discussion. Also see Luce (1959) and McFadden (1979).
} 


\section{The Decision of Whether to Attend}

The conditional logit model above will estimate the choice between colleges, but an individual must also decide whether to attend college at all. As stated in equation (4), the individual will compare his options and choose the alternative that maximizes his lifetime utility subject to his budget constraint. His options will include attending college, entering the labor force, or not working at all. Traditionally, researchers have used state-level measures of college characteristics to approximate the college option, but as discussed above, this masks a great deal of heterogeneity and may not be a good proxy for the actual school the individual might be considering. ${ }^{16}$ Therefore, using the parameters of the conditional logit model, I predict the college that is the most likely college alternative if the individual does decide to attend. A basic logistic model is then used to estimate the likelihood of enrollment with the characteristics of this most likely school being used to understand how individuals weight the prospects of college attendance against outside options.

This estimation strategy assumes that individuals make decisions between colleges in the same way regardless of whether they decide to attend or not. This may be a concern if students who do not attend do not properly weight their options or lack the information needed to make decisions that would maximize their utility. However, for most students likely to be on the margin of attendance, the predicted option is the nearest two-year or four-year, public college. Most students are aware of these local options from peers, high school resources, and the local press. Furthermore, the data suggests the individuals with similar observable characteristics make different college decisions due to the local higher education options available to them. Several studies suggest that individuals from more disadvantaged backgrounds are more likely to attend if they have a nearby college option with a reasonably low tuition price (Rouse, 1994; Kane, 1995). Therefore, differences in enrollment may be due to the options available and not that the decision-making process differs by background. In any case, using the "most-likely" college is a better approximation of the outlook of a prospective student than the state-level measures of public tuition levels previously used. 
In analyzing the determinants of the enrollment decisions, I focus on the group with the highest propensity to be on the margin and compare the opportunities of those who attended to those who did not. This group includes low-income, low-ability individuals who are likely to face high costs for securing capital and fewer benefits from college attendance assuming that ability and education are complements. As such, this group will be highly sensitive to the opportunities they face. While they may decide to invest in higher education given one set of opportunities, when presented with another set of alternatives, they may not enroll at all. By exploiting the variety of opportunities available to students based on their residence, I estimate the effect of college characteristics on the attendance decision.

\section{Concerns about Endogeneity and the Supply Side of College Demand}

The conditional logit choice model avoids some of the fears of misinterpretation associated with aggregated, cross-sectional analysis since I am able to view the specific options available to a student rather than just the means of groups of alternatives. However, endogeneity problems could arise if individual or group preferences within a state influence aid policy. Unobserved tastes for education could affect how and why subsidies are distributed within a state in a certain way, and these preferences would in turn influence college decisions, thereby biasing estimates. For example, states with stronger preferences for education might choose to support a wide range of options in order to attract and educate all types of students. Meanwhile, a state without these preferences might choose to offer colleges that only provide basic education and are not selective. Therefore, whether a high-ability student is able to attend a competitive, in-state public college would be influenced by the underlying preferences of his or her state of residence. Moreover, how a state prioritizes the education of certain groups could also have an affect on the distribution of subsidies. For instance, a state's commitment to the education of lowincome, low-ability, or older individuals might affect its generosity to two-year colleges. Concerns about endogeneity are mitigated by the fact that states with similar observable characteristics have vastly

\footnotetext{
${ }^{16}$ Manski and Wise (1983) highlight the importance of an appropriate choice set by utilizing information on the colleges accepted to and the nearest community college as possible college options. Then, they estimate a multinomial logit to explain the choices individuals made between college and outside opportunities.
} 
different subsidy schemes. One reason for this is that the patterns of public colleges in a state and the distribution of tuition subsidies are strongly influenced by historical factors. ${ }^{17}$

The problem of unobserved preferences is likely to be most serious for marginal students because these individuals are most sensitive to the specific characteristics of potential colleges. To illustrate, suppose state preferences affect the placement of colleges in particular areas of the state. Since the proximity of schools appears to be a determining factor in the attendance decisions of marginal students, this group would therefore be influenced by the state's unobserved preferences interacted with each individual's specific residence. However, because colleges appear to be distributed among heterogeneous communities in more populous states, this is a potential problem for estimation mainly in more-rural states. To address the concern that the assignment of location could unduly drive the choices of some individuals, specification tests are used to verify the results. ${ }^{18}$

Another concern of this methodology is its focus on the demand side of college decisions without explicit treatment of supply-side constraints. It is first important to note that the vast majority of institutions are not selective and a large majority of students are accepted into their first-choice college. ${ }^{19}$ Moreover, the conditional logistic choice model accounts for supply considerations in two ways. First, because a student's ability relative to that of a college's student body may be an important determinant of enrollment at that school, the model includes variables that measure the difference between the student's SAT percentile score and the median percentile score of the school. These variables, therefore, account for the likelihood of admission and prevent the model from predicting that individuals with low test scores would be accepted into the most selective schools. Additionally, the model includes controls for undergraduate enrollment to account for the fact that larger schools have a higher level of visibility and are able to admit greater numbers of students.

\footnotetext{
${ }^{17}$ See Goldin and Katz (1999) and Quigley and Rubinfeld (1993) for a discussion of how historical factors influenced the development of public higher education.

${ }^{18}$ For the state simulations, I randomized each student's location assignment several times to examine whether the results vary. They changed little and never disputed the paper's basic results. See below for further discussion. ${ }^{19}$ According to Breland, Maxey, Gernand, and Trapani (2002), only 13 percent of public four-years and 20 percent of private four-years have competitive admissions processes. Most other four-year schools do impose selective criteria such as high school course requirements and minimum test scores, but they accept nearly everyone who
} 


\section{The Data}

Several data sets provide the necessary individual, institutional, and state-level data. First, the National Education Longitudinal Study (NELS) provides information on the characteristics, ability, and family background of approximately 8,000 students from eighth grade to age twenty. ${ }^{20}$ During this time frame, I am able to observe transitions from high school to postsecondary education or the workforce including the application to and enrollment in college. A second study, the Integrated Postsecondary Education Data System (IPEDS) provides extensive information on postsecondary institutions within the United States including financial expenditures and revenues, tuition costs, and enrollment. ${ }^{21}$ These data were supplemented by information from the Digest of Educational Statistics and U.S. Department of Commerce for state-level characteristics. Barron's Profiles of American Colleges provided information on college competitiveness and student body test scores. ${ }^{22}$

In order to have a better sense of net price, the amount of Federal Pell Grants that a person could expect to receive was subtracted from the list tuition price. The lack of information about aid beyond Pell Grants is not a great concern given few students receive substantial grants. In 1991-92, the median college spent only \$193 in institutional aid per student. Moreover, according to the 1992-93 National Postsecondary Student Aid Survey (NPSAS), only one-third of students at private four-year colleges and ten percent of students at public four-year colleges received any institutional grant aid. ${ }^{23}$ Students who

meets those criterion. Ninety-one percent of public two-year colleges and 46 percent of private two-year colleges have completely open admissions without requirements. The rest have minimum standards.

${ }^{20}$ While the original data set in 1988 contained 14,622 observations, once accounting for attrition by 1994 , only 7,870 observations remained with the necessary information. This sample has slightly higher mean years of parental education (14.07 years in the original compared to 14.44 years), slightly higher family income (as measured by a categorical variable), and were more likely to have attended a private high school ( 9.7 percent compared to 14.7 percent). If the student's SAT score was not available, then either: (i) an available ACT score was converted, or (ii) high school GPA was used to predict the SAT with controls for demographics.

${ }^{21}$ The sample was limited to nonspecialized, undergraduate institutions. Carnegie codes and school names were used to drop the following schools from the sample: graduate programs and other specialty schools (art college, seminaries, etc.); college administrative offices; schools without tuition and enrollment information; single-sex colleges. For schools that did not have student expenditure information in 1992, figures from other years were used and deflated. A total of 2,669 colleges remained in the sample.

${ }^{22}$ If the median score was missing for a college but the school was grouped into a competitiveness category, the test score assigned is equal to the mean score of colleges in that category. Since two-year colleges do not customarily require or request test scores, all were assigned an SAT composite of 700, a level that qualifies basically all students.

${ }^{23}$ Institutional Aid is most likely to affect the net price for high-ability students. To address this concern, I tried an alternative measure of price equal to the list tuition price minus the expected Pell Grant minus the mean institutional grant per FTE student at a college (a proxy for net price). When using this alternative measure, price is estimated to 
do receive scholarships or grants often do so from only a few schools within their opportunity sets making the awards school-specific and nearly impossible to predict. Furthermore, information on a student's specific need is unavailable. Distance from a school was calculated using the zip code of the student's high school (the finest geographical indicator in the NELS) and the potential college.

To measure college resources, the models include expenditures. However, because total college expenditures include many items that do not directly affect education production (i.e. research and infrastructure), I only include student-focused expenditures: funds spent on instruction, academic support, and student services. ${ }^{24}$ Median student body SAT score proxy for peer resources. Since a difference of 100 points does not mean the same thing at all places in the distribution of scores (e.g. a 400 versus 500 compared to a 1500 versus 1600 ), the median score was transformed into a percentile to better standardize the measure. Quadratic tuition, distance, test score, and student expenditure variables along with a cubic distance variable are included to allow for nonlinear relationships. This is necessary because, for example, the difference between a distance of 20 to 30 miles may not be the same as a difference of 1200 to 1210 miles. Table 1 summarizes the data and variable definitions.

\section{SECTION IV: THE DETERMINANTS OF COLLEGE CHOICE AND ENROLLMENT}

\section{Estimates of the Decisions between Colleges}

Table 2 displays the estimates of the conditional logistic model using students in NELS that attended college. I estimate the probability of choosing at a particular college conditional on attending any postsecondary institution. As shown in specification 1, a higher tuition price has a negative effect on the probability of enrollment at a particular school. A student is 39 percent less likely to attend a college that charges an additional $\$ 1,000$ in tuition costs, ceteris paribus (1992 dollars). This translates into an

\footnotetext{
have a more negative effect on the likelihood of choosing a particular college. However, the alternative measure of price did not improve the predictive value of the model. The original measure of price produced better predictions of the students' actual choices even among the high-ability students. The college with the highest choice probability is the same with each price measure 91 percent of the time.

${ }^{24}$ Schools found to have unreasonably high student expenditures in comparison with similar schools were assigned the mean expenditures for that type, quality, and level of school. Data for 11 colleges had to be adjusted.
} 
own-price elasticity of $-2.8 .^{25}$ However, each additional $\$ 1,000$ has a less negative effect on choice. Distance, another measure of cost, also negatively affects the likelihood of attendance at a school. A student is 81 percent less likely to attend a school that is 100 miles farther away than a similar college, but the marginal negative effect of distance decreases.

In contrast, school resources, as measured by expenditures, the student-faculty ratio, and the percent of the faculty with a Ph.D. or other terminal degree, have a positive effect on the likelihood of choosing a college. The student-college match and school resources are also found to be important determinants of college choice. The likelihood of attendance at a college decreases 29 percent for every ten percentile-points that the student's score is above that of the college's average student. The relationship is found to be positive if the school's scores are higher perhaps signifying that students try to attend colleges with peers of higher quality. However, as the marginal difference between a student's test score and that of a school grows, individuals become less likely to attend that college. School size is also positively related to the likelihood of attendance.

Since the effect of school costs and resources may differ by student, interactions were utilized in specification 2. The impact of cost on low-income individuals is examined using an interaction with a dummy variable equal to one for individuals with family incomes below $\$ 20,000$ in 1991 . While tuition is not found to have an additional negative effect on the likelihood of choosing a college, distance, another measure of cost, reduces the likelihood of enrollment by an additional 35 percentage points. High-ability students also seem to be affected differently by school characteristics. Tuition has a less negative effect perhaps suggesting that high-ability students expect a higher return to college and are therefore willing to pay more for their educations. It could also reflect the fact that this group is more likely to receive institutional financial aid, which could help to cover higher costs, or that they may be more likely to come from more affluent backgrounds. Moreover, a college that is 100 miles farther away is only 36 percent less likely to be chosen by a high-ability student while a $\$ 1,000$ increase in student

\footnotetext{
${ }^{25}$ While there is limited empirical evidence on the specifics of competition between colleges, several other papers have found significant cross-price effects for specific institutions (see Allen and Shen (1999) for further discussion). However, this is the first paper to estimate such effects for the entire higher education market.
} 
expenditures multiplies the likelihood of attendance by an additional 15 percentage points for the first $\$ 1,000$, ceteris paribus.

\section{Estimates of the Enrollment Decision}

The second specification in Table 2 gives a prediction of what school an individual would choose conditional on attendance. However, some students will elect not to enroll in college at all. This could be related to the opportunities available since an individual might not attend college facing one set of alternatives and prices but do so given a different distribution of subsidies and costs. Individuals for whom the enrollment decision is uncertain are most likely of lower ability (and therefore confront uncertain or low returns to education) or low-income (and face extremely high capital costs). This seems to be true as evidenced by the mean demographics of the group in the NELS that elected not to attend college. ${ }^{26}$ Therefore, to analyze the attendance decision, the group of students who did not attend college are compared to individuals with similar characteristics but who decided to attend college using logistic regression models. ${ }^{27}$

This marginal group presumably considers local public college options, particularly two-year colleges, when deciding whether to attend since these schools are less of a commitment in terms of cost and distance. ${ }^{28}$ Therefore, in order to estimate how local higher education opportunities affect the likelihood of enrollment, the characteristics of the closest two-year public college and the closest fouryear public college were used. As shown in Table 3, specification 1, while distance and student ability appears to affect college attendance, the price of the closest public two-year net an expected Pell Grant does not. When the closest public four-year college is used as the focus, neither price nor distance are found to affect likelihood of attendance. However, the characteristics of the nearest public two-year or four-year college may not be true variables of interest for a student considering enrollment.

Specification 3 instead uses the college predicted to be the most likely choice from the conditional logit

\footnotetext{
${ }^{26}$ Individuals who did not attend college had a mean family income of $\$ 34,818$ while the families with child who enrolled made on average $\$ 57,370$. Likewise, the mean SAT scores for the groups were 786 and 913 , respectively.

${ }^{27}$ The criteria for this group were: (1) family income below $\$ 30,000$, or (2) parents' with less than 13 years of education, or (3) SAT scores below 900. The sample included 2,177 students who did not and 3,484 who did attend.
} 
model in Table 2, specification 2. These predicted colleges are often either the closest two-year public college (14 percent of the time) or the closest four-year public college (36 percent of the time), and therefore, specification (3) is partly a combination of the first two specifications.

Using the school predicted to be the student's most likely choice, it is estimated that an additional $\$ 1,000$ in list tuition price reduces the likelihood of attendance by 7.8 percent suggesting a price elasticity of -0.30 . This elasticity is a third larger than that found by Kane (1995). This may suggest that previous estimates of the price elasticity have underestimated the influence of cost by using aggregated measures. The state mean tuition level or nearest public college may not approximate very well the college characteristics important to students in the early 1990s perhaps due to the decreasing cost of distance. However, given that this sample of marginal students is expected to be more responsive to price than others, it is likely that this estimate of the price elasticity is an upper bound.

\section{Comparing Actual to Predicted College Investments}

In order to test the ability of the model to adequately predict the college decisions of individuals, Table 4 compares the actual choices of individuals and their predicted choices using the parameters in Tables 2 and 3. The entire sample of individuals (whether they attended college or not) was used for the predictions in the following way. First, I calculated the probability that an individual would choose a particular school relative to their other options using equation (5) and the parameters of the model in Table 2, column 2. Second, I calculated the likelihood of attendance for each person given the characteristics of the most-likely college. This develops from the parameters of the model in Table 3, column 3. ${ }^{29}$ Each student-college match was then weighted by each of these probabilities. This process gives mean statistics taking into account both the relative odds of choosing a particular school and the likelihood of enrollment.

As shown in Table 4, the model predicts college choices with very similar statistics as those schools that were actually attended. For example, while 3,841 individuals in the sample actually

\footnotetext{
${ }^{28}$ Rouse (1994) suggests that junior colleges provide a place in higher education for those not traditionally served by the four-year college system. She also demonstrates that proximity is important to the marginal group.

${ }^{29}$ The parameters are used to calculate the probability of enrollment for each individual in the marginal group at each potential college. Individuals not in the marginal group were given an enrollment probability of one.
} 
attended a four-year college, the model predicts that 3,829 would. In addition, the mean list tuition at the colleges attended was $\$ 5,863$ while the model predicted it would be $\$ 5,634$, a four-percent difference. The model does a slightly better job predicting the college costs and resources of those that attend fouryear schools than those that attend two-year colleges. However, the model does overestimate the proportion of students that choose to attend public, four-year colleges.

Differences between the actual and predicted choices could be due to several reasons. First, prospective students may not have full information about all of their potential schools in order to make the most optimal decisions. For example, they may elect to attend a more expensive school if they do not know about a cheaper option with the same student expenditures that is a similar distance away. The differences could also occur since the variables do not perfectly describe each college option. Colleges may have more to offer than can be measured by expenditures and student body test scores, and these qualities may be perceptible to students. Furthermore, differences may be due to the fact that private and institutional financial aid enable students to attend more costly colleges with more resources. I am unable to incorporate these types of aid into the model due to a lack of information (see the earlier discussion of this point).

Another explanation for the differences is the lack of explicit supply constraints in the model. I do not directly take into account admissions policies, and therefore, students could possibly be predicted to attend a college they have little likelihood of being accepted into. However, the test score difference variables in the model seem to account for most of the selectivity issues. On average, the school percentile predicted does not differ much from what it was in reality. The model avoids predicting options in which there are great differences between the test scores of the individual and of the school.

Further support that the model does a good job of predicting decisions comes from the fact that the actual school attended was one the top three predictions in nearly one-third of the cases. However, the fact that the model does not always predict the exact school an individual attended does not matter if the school predicted is similar to the school actually chosen (e.g. Harvard is predicted but Amherst is chosen). This is because the important characteristics of the schools, tuition and student expenditures, will be the same in the data. There would be concern if Harvard was the predicted choice, but the 
student attended a community college instead. The predictions do follow the general trend that highability students opt for schools with higher test scores and student expenditures while low-income students attend two-year colleges more often, travel shorter distances, and pay less in tuition.

\section{SECTION V: THE EFFECT OF IN-KIND TUITION SUBSIDIES}

Because tuition costs seem to greatly affect the probability of enrollment at a particular college, individuals may accept lower quality (i.e. fewer resources) for the sake of price. The state subsidization of public colleges and resulting price gap between public and private options provides an opportunity to test this notion set forth by Peltzman. Two sets of simulations are performed. The first involves altering the state of residence of the individual to see how his decision would change given a new distribution of subsidies and colleges. This simulation compares how state regimes affect enrollment levels, the prices charged, and the resources received. The second simulation explores the counterfactual of what would happen if the aid were not in-kind. Using the same state spending amounts, I examine how decisions would change if students were instead given a voucher that was applicable to any in-state college.

\section{State Simulations}

As shown in Figures 1 and 2, California and Massachusetts have considerably different systems in terms of the distribution and level of state in-kind tuition subsidies. However, each seems to have a strong commitment to education. Massachusetts has long been a leader in education indicators, and in 1992, the percentage of its population with a bachelor's degree was the highest in the nation (27.2 percent). Likewise, California has a very educated population with almost a quarter of its people with at least a bachelor's degree. The substantial financial state support of colleges in California may also be taken as a signal of its commitment to higher education. Therefore, with strong preferences for education and subsidy policies that differ significantly, Massachusetts and California are excellent states to compare and assess the effect of dissimilar state in-kind tuition programs. To round out the state comparisons, predictions are also made for Illinois and Nebraska. Each has a distribution of subsidies in the middle of Massachusetts and California. Unlike Massachusetts, Illinois (Figure 4) offers a highly competitive, public option, but it is the only option, and it does not receive as much state aid or spend as 
much in resources as the top-rated schools in California. Finally, Nebraska (Figure 5) has a similar distribution of public schools as Massachusetts, but the state aid level is higher allowing a good test of whether large subsidies influence students to forego private options. However, unlike the other states, Nebraska does not have any private colleges ranked in the Most or Highly Competitive groups, but students at Creighton University receive the same amount in expenditures as do students at many colleges rated Most Competitive.

To compare the decisions that would be made under each state's subsidy regime, the sample was first given the characteristics of a state resident. For example, for the California predictions, the tuition values became in-state costs for California colleges and out-of-state costs for other schools. Location in the state was randomized based on the distribution of the population among zip codes (i.e. Los Angeles zip codes were assigned to members of the sample in an equal proportion to the number of Californians that reside there). For each location assignment, a new distance variable was calculated to each potential college. ${ }^{30}$ Table 5 displays the summary statistics of the predicted college decisions when presented with the revised opportunity sets based on residence within each state.

The greatest differences are between the states with the two extreme subsidy systems. California, with the most generous state support, has the highest percentage of students in public colleges and the lowest mean four-year tuition cost of the four states. Even with the lower cost, students under the California system are predicted to experience the highest level of college expenditures and median student body SAT percentile due to the quality of institutions supported and the large tuition subsidies. At the other end of the spectrum, Massachusetts, with much less state support, is predicted to have more than one-third fewer students in public colleges with students paying nearly three times more in fouryear tuition costs on average without increases in college expenditures. More students are predicted to attend college under the generous California regime although many are predicted to attend two-year

\footnotetext{
${ }^{30}$ As mentioned earlier, this methodology could affect the results because the placement of colleges may not be random, and proximity is an important determinant of enrollment. For example, community colleges may be located in poorer areas, but since poorer individuals are not necessarily assigned to live in those areas, their likelihood of attendance may be underestimated. However, in metropolitan areas, community colleges are found in both poor and rich areas minimizing this type of problem. This is a greater concern for rural areas. In order to get the most reliable results, the simulations were run several times for each state with a new random location assignment each time. The predictions did not significantly differ thereby suggesting this concern is not significant.
} 
colleges with an average tuition price one-eighth the average cost of the two-year colleges chosen in Massachusetts.

The differences among the subset of high-ability students are also striking. Nearly three times as many high-SAT students are predicted to choose public four-year colleges in California, and they are predicted to be charged one-third of the average tuition relative to Massachusetts. More specifically, as residents of California, many high-ability students would attend UCLA or UC Berkeley due to their low costs and substantial resources. However, in Massachusetts some high-ability students would elect to attend selective private institutions such as Harvard University and pay five and a half times more while only receiving 30 percent more in student expenditures. Although this study does not take into account institutional scholarships, this aid is unlikely to completely close the tuition gap between Harvard and UC Berkeley for middleclass families. In summary, when faced with California's generous subsidies and diverse system of public colleges as opposed to Massachusetts' less generous and limited array of public options, individuals paid far less but received a similar amount in resources.

Illinois and Nebraska demonstrate how choices are affected in subsidy regimes closer to what most states offer. In each case, more students are predicted to choose public colleges than under the Massachusetts system, but unlike in California, students do not receive as much on average in college expenditures and student body quality (SAT percentile). The reason stems from the fact that neither state offers public institutions with nearly as much in resources or peer quality as California but the low price of these colleges is sufficient enough to encourage students to attend them. For example, in the Illinois simulation, many high-ability students are predicted to choose the University of Illinois-Urbana over Northwestern University and the University of Chicago. This suggests that the discounted tuition price of an in-state, public four-year university is enough to encourage some individuals to forego schools with more resources, the precise concern of Peltzman. Further evidence of the Peltzman hypothesis is found by examining the predictions for Nebraska. Approximately 76 percent of four-year college students would choose to attend a public institution if they were residents of Nebraska, and the mean student expenditures and student body test scores are the lowest of the four states. The fact that none of the 
public options in Nebraska fit the criteria of more selective schools translates into less in college financial and peer resources.

The Peltzman hypothesis, therefore, appears valid in situations in which the level of state aid is average to high but the availability of public options with high levels of resources is limited. Such circumstances are predicted to induce students to choose public colleges that offer fewer resources than private, more expensive options. In essence, students are enticed by lower prices to forego college resources. It is also worth noting that low-income students appear to be particularly attracted to the public options regardless of the state subsidy level or distribution of public college quality. The percentage of low-income students predicted to choose public colleges in Massachusetts is only onequarter less than in California, a far smaller difference than that found for the sample overall or among the subset of high-ability students.

\section{Voucher Simulations}

A better way to test the importance of the Peltzman hypothesis is to simulate what choices would be made if the aid were not in-kind. Tables 6 and 7 describe five alternative ways in which the aid could be distributed. It is important to note that these simulations do not estimate general equilibrium outcomes. While the simulations incorporate some thought to how student decisions might change under different circumstances, I do not adequately incorporate a student behavioral response in the simulations. ${ }^{31}$ Furthermore, I do not account for how the supply of higher education might change under different distribution regimes. If a college voucher encouraged more students to choose private colleges, it is unclear whether the private institutions would be able to accommodate the additional students or by how much or how fast they would try to increase their capacity. However, the simulations do provide a manner with which to judge the magnitude of the influence of the in-kind format. In effect, the predictions suggest how college preferences or intended choices might change if state subsidies were not distributed in an in-kind format.

\footnotetext{
${ }^{31}$ For example, the voucher simulations assume that a greater proportion of students might choose to attend four-year colleges and that more students might choose to remain in state. The simulations also assume perfect information, a particularly troublesome assumption for low-income students.
} 
Column 1 of Tables 6 and 7 presents the mean tuition prices and predicted college decisions under the current in-kind subsidy system. However, at the other extreme, states could elect not to appropriate any operational support to public colleges thereby eliminating in-kind tuition subsidies. ${ }^{32}$ As shown in column 6 of Table 6 , the prices of public colleges are assumed to increase by the amount of state appropriations per FTE student at each public college. ${ }^{33}$ While tuition costs do not vary significantly among public four-year colleges of different competitiveness levels under the current system, if state subsidies were taken away, the more selective schools would be much more expensive than the less competitive and noncompetitive colleges. This reflects the larger amount of state aid directed to more selective public institutions. Additionally, the gap between public two-year and fouryear colleges would grow since four-year institutions receive more in state operational subsidies. The price of private colleges would not change. However, even under a situation of no state support, private colleges are still more expensive than public colleges of similar competitiveness. For example, competitive public colleges cost 28 percent less than competitive private colleges on average, partly due to differences in expenditures per student. Therefore, public colleges continue to have a relative price advantage even without the state support.

Table 7, column 6 displays how college decisions are predicted to change under a system with no state support. Two major trends are evident. First, state support is found to significantly affect the choice of college sector. The simulation without state support suggests far fewer students would choose to attend public four-year colleges. Although 71 percent of four-year attendants are predicted to do so under the current system, only 56 percent would choose publics if there were no state support. In terms of the number of students, 29 percent fewer individuals would choose public four-year colleges under a system without state aid (2,706 versus 1,925 students). Low-income students would be especially impacted, as 38 percent fewer would choose public four-year colleges without a subsidy. At the same time, the number electing to attend a private college is predicted to

\footnotetext{
${ }^{32}$ All of the following simulations assume that state grant programs are not affected. The focus here is on how state appropriations to colleges could be redistributed.

${ }^{33}$ The price of in-state public colleges is assumed to be the in-state price plus the increase due to the loss of state appropriations. Out-of-state public colleges are assumed to charge the greater of the out-of-state price and the revised in-state price.
} 
increase by one-third from 1,123 to 1,489 students. This suggests that state in-kind subsidies strongly influence students to favor public colleges over private institutions.

A second observation is that more students would attend two-year rather than four-year colleges if states did not provide operational support. The number predicted to enroll in two-year colleges increases by 14 percent. The shift in enrollment is more substantial among low-income students: one-third more low-income students are predicted to choose to attend two-year colleges. This result implies that the current pattern of in-kind subsidies encourages students to not only attend public colleges, but in particular, public four-year colleges. Note also that although total enrollment is not predicted to significantly drop without state support, a shift in enrollment towards community colleges would have important implications for the general skill level of the labor force given the differences in resources and programs available at colleges of different levels.

The remaining simulations consider how prices and decisions would change if states continued to provide the same amount in appropriations for higher education, but the subsidies were distributed in the form of a direct voucher to students. In this way, the state aid would be similar to the Pell Grant in that it would follow the student to the institution of his or her choice. The value of the voucher is the total state appropriations for nonspecialized colleges divided by the FTE number of students attending these colleges (for simulations 2 and 3, only students attending public colleges were counted). ${ }^{34}$ In the simulations in which the four-year voucher is twice as large as the two-year voucher (simulations 3 and 5), 70 percent of students are assumed to attend four-year schools. ${ }^{35}$

For the simulations in columns 2 and 3, the state subsidy could be used at any in-state public college. In column 2, the voucher is the same regardless of the level of the public college (this is similar to the current Colorado college voucher proposal) while the voucher is twice as large for four-year colleges in column 3. These simulations not only remove the in-kind format of the aid, but they also equalize the amount of operational support among public colleges within a state. As shown in Table 6, because two-year public colleges often receive less than half of what four-year colleges receive, under a

\footnotetext{
${ }^{34}$ This assumes a usage rate of 100 percent. Presently, around 85 percent of students remain in state for college.

${ }^{35}$ The value of the voucher for four-year colleges can be found by solving: appropriations/student $=.7 \mathrm{x}+.3(\mathrm{x} / 2)$. This is slightly larger than the proportion that does so under the current system.
} 
public voucher plan, many of these schools would experience reductions in price in comparison to the current in-kind system. Moreover, because the more selective institutions receive a larger share of state appropriations, this redistribution scheme would cause many of the public flagship colleges to raise their prices. These price shifts influence how enrollment might change under a public college voucher system. As shown in Table 7, columns 2 and 3, the vouchers are predicted to increase the number of students who would choose two-year colleges. This change is particularly large among high-ability students of whom 53 percent more are predicted to choose two-year colleges if the voucher was the same regardless of level. Overall, the resources available to students at their chosen institutions would slightly decrease. This suggests that if state support were equalized across all public colleges, the Peltzman problem would be far greater. The incentives created under such a system would cause many more students to forego educational resources for the sake of price.

The remaining price gap between public and private colleges and the continued favoritism of public schools under the public college voucher simulations results in nearly the same proportion of students choosing public colleges. The last two simulations remove the public dimension of the aid completely by allowing students to apply the state voucher to any in-state public or private institution. As shown in columns 4 and 5 of Table 6 , the voucher was recalculated as total state appropriations divided by the total FTE enrollment at all in-state nonspecialized colleges. This amount was then subtracted from all in-state college prices, public and private. This thereby equalizes the distribution of the subsidy by level and selectivity but also by sector. The only remaining difference between public and private schools is control. In comparison to the current in-kind subsidy system, this voucher plan would reduce the costs of less competitive colleges the most while also reducing the price difference between public and private institutions.

When the state aid is distributed as a voucher that could be applied to any in-state public or private college, the number of students predicted to choose public four-years falls (columns 4 and 5 of Table 7). If the voucher were equal regardless of the level, the number of students enrolled at public four-year colleges would fall 24 percent. While many students would shift to public two-year colleges, the number choosing private four-year colleges is predicted to increase 20 percent in comparison to the 
level under the current in-kind subsidy system. If the voucher for four-year colleges was instead twice as large, the number at public four-year colleges is predicted to fall 14 percent but many more students would choose private institutions. The number electing to attend a private four-year institution would increase 29 percent. This difference lends support to Peltzman's assertion that in-kind tuition subsidies at public colleges draw students away from private options. However, the change in sector did not result in an increase in the mean resources received by students. In each case, the response of low-income students is predicted to be far greater. This suggests that the distortion created by the in-kind state subsidy is strongest for these students possibly due to their heightened sensitively to price. In summary, without the in-kind format, many more students would opt out of the public higher education system.

\section{SECTION VI: CONCLUSION}

The conditional logit model is an improvement in estimating the determinants of college choice. While models that use state cross-sectional variation to estimate student decisions ignore much of the heterogeneity in the market for higher education, my model exploits this variation to estimate the effect of cost and quality on the decisions of whether to go to college and which college to attend. Conditional on college attendance, higher tuition costs and distance reduce the likelihood of choosing a particular college while student expenditures increase the probability. These effects differ for particular groups. High-ability individuals are more influenced by quality measures, and low-income students are more responsive to distance. When individuals consider whether to enroll, price appears to be an important factor. Once determining the college the individual is most likely to consider by using the choice model, the elasticity of price with respect to enrollment is estimated to be much larger than previously found.

Using this college choice model to examine students' decisions, it is clear that the current state in-kind subsidy system creates a series of incentives in terms of college decisions. First, students are induced to favor in-state, public institutions. As shown by the simulations, the larger the tuition subsidy, the more likely students will forego a private or four-year option even if it offers far more in resources. Therefore, there appears to be validity to Peltzman's hypothesis that in-kind subsidies could reduce educational investment. 
Removing the in-kind format and public focus of the aid would avoid some of the concerns of Peltzman by reducing the price gap between public and private colleges. As shown by the voucher simulations, up to 24 percent of first-year students would no longer prefer a public, four-year school if given the money as a voucher that could be applied to any in-state college (the decrease is smaller if the voucher were twice as large for four-year colleges). As a result, the number that would choose to enroll in a private four-year college would increase 20 to 29 percent. Given enrollment rates in 1992, this suggests that an additional 80,000 to 120,000 freshman would prefer to attend a private four-year college each year if the in-kind format of state subsidies was removed. The number of students choosing to attend private four-year colleges would increase by 575,000 to 830,000 students. While this is not a true estimate of the general equilibrium outcome of a voucher program given the absence of behavioral and supply responses, these results do suggest that the distortion of choice by the in-kind format is substantial. If states stopped giving subsidies altogether, the difference would be even larger. Without any state support, 29 percent fewer students overall and 38 percent of low-income students are predicted to attend public four-year colleges. The number attending private four-year colleges would increase by one-third.

In addition to creating preferences for public colleges, the pattern of state in-kind subsidies also favors public four-year over two-year institutions and more selective schools over those that are less competitive Simulations in which the state subsidies are equally distributed among public colleges suggest that students would choose inexpensive two-year colleges over four-year school with far greater resources. This provides further support of the influence of the in-kind aid can have on college decisions. However, because the four-year institutions have more in resources, the distortion in price between two- and four-year public schools is probably beneficial in terms of individual college investments. 


\section{$\underline{\text { REFERENCES }}$}

Allen, Robert F. and Jianshou Shen. "Some New Evidence of the Character of Competition among Higher Education Institutions.” Economics of Education Review, vol. 18, no. 4, 1999.

Barron's Educational Series. Barron's Profiles of American Colleges. $21^{\text {st }}$ Edition. Hauppauge, New York: Barron's Educational Series, 1997.

Borsch-Supan, Axel. "Econometric Analysis of Discrete Choice.” In M. Backmann and W. Krelle, eds. Lecture Notes in Economics and Mathematical Systems. Berlin: Springer-Verlag, 1987.

Breland, H., J. Maxey, R. Gernand, T. Cumming, and C. Trapani. Trends in College Admission 2000. ACT, Inc.; Association for Institutional Research; Educational Testing Service; the National Association for College Admission Counseling; and the College Board, 2002.

Cameron, Stephen and James Heckman. "Can Tuition Policy Combat Rising Wage Inequality?" In Marvin H. Kosters, ed. Financing College Tuition: Government Policies and Educational Priorities. Washington: The American Enterprise Institute Press, 1999.

Campbell, R. and B. Siegel. "The demand for higher education in the United States 1919-1964." American Economic Review, vol. 57, 1967.

Clotfelter, C. T. "Public Spending for Higher Education: An Empirical Test of Two Hypotheses." Public Finance, vol. 31, 1976.

College Board. Trends in College Pricing. Washington: The College Entrance Examination Board, 2002.

Ganderton, Philip T. "The Effect of subsidies in kind on the choice of a college." Journal of Public Economics, vol. 48, 1992.

Goldin, Claudia and Lawrence Katz. "The Shaping of Higher Education: The Formative Years in the United States, 1890 to 1940.” Journal of Economic Perspectives, vol. 13, no. 1, 1999.

Gottlieb, Bruce. “Do Public In-Kind Subsidies to Education reduce Social Welfare?” Harvard University mimeo, 1997.

Hansen, W. Lee and Burton Weisbrod. "The Distribution of Costs and Direct Benefits of Public Higher Education: The Case of California.” Journal of Human Resources, vol. 4, no. 2, 1969a.

Hansen, W. Lee and Burton Weisbrod. "On the Distribution of Costs and Direct Benefits of Public Higher Education: Reply.” Journal of Human Resources, vol. 4, no. 3, 1969 b.

Hopkins, T.D. “Higher Education Enrollment Demand.” Economic Inquiry, vol. 12, 1974.

Hoxby, Caroline. "The Changing Market Structure of U.S. Higher Education." Harvard University mimeo, 1997.

Hoxby, Caroline and Bridget Terry (Long). "Explaining Rising Income and Wage Inequality among the College-Educated.” National Bureau of Economic Research Working Paper No. 6873, 1999.

Johnson, George. “Subsidies for Higher Education.” Journal of Labor Economics, vol.2, no. 3, 1984. 
Kane, Thomas. "Rising Public College Tuition and College Entry: How Well do Public Subsidies Promote Access to College?" National Bureau of Economic Research Working Paper No. 5164, July 1995.

Leslie, Larry and Paul Brinkman, The Economic Value of Higher Education. New York: Macmillan Publishing Company, 1989.

Long, Bridget Terry (forthcoming) "How Have College Decisions Changed Overtime? An Application of the Conditional Logistic Choice Model.” Journal of Econometrics.

Luce, R. Individual Choice Behavior. New York: Wiley, 1959.

McFadden, Daniel. “Conditional Logit Analysis of Qualitative Choice Behavior” In P. Zarembka, ed. Frontiers in Econometrics. New York: Academic Press, 1973.

McFadden, Daniel. "Quantitative Methods for Analyzing Travel Behavior of Individuals: Some Recent Developments.” In D. Hensher and P. Stopher, eds. Behavioural Travel Modelling. London: Croom-Helm, 1979.

McPherson, Michael and Morton O. Schapiro. "Does Student Aid affect College Enrollment? New Evidence on a Persistent Controversy." American Economic Review, vol. 81, no. 1, 1991.

Manski, C. and D. Wise. College Choice in America. Cambridge: Harvard University Press, 1983.

National Center for Education Statistics. Digest of Education Statistics. Washington, D.C.: Department of Education, various years.

Palmer, James. Grapevine. Bloomington, IL: Illinois State University, Center for the Student of Education Policy, 2003.

Pechman, Joseph. "The Distributional Effects of Public Higher Education in California." Journal of Human Resources, vol. 5, no. 3, 1970.

Pechman, Joseph. "A Note on the Intergenerational Transfer of Public Higher-Education Benefits." Journal of Political Economy, vol. 80, no. 3, Part II, 1972.

Peltzman, Sam. "The Effect of Government Subsidies-in-Kind on Private Expenditures: The Case of Higher Education." Journal of Political Economy, vol. 81, no. 1, 1973.

Poterba, James. "Government Intervention in the Markets of Education and Health Care: How and Why?" in Victor R. Fuchs, ed. Individual and Social Responsibility. Chicago: The University of Chicago Press, 1996.

Quigley, John and Daniel Rubinfeld. "Public Choices in Public Higher Education.” In Charles T. Clotfelter and Michael Rothschild, eds. Studies of Supply and Demand in Higher Education. Chicago: The University of Chicago Press, 1993.

Rouse, Cecelia. "What to do after High School: The Two-Year versus Four-Year College Enrollment Decision." In Ronald G. Ehrenberg. Choices and Consequences: Contemporary Policy Issues in Education. Ithaca: ILR Press, 1994.

Sonstelie, Jon. “The Welfare Cost of Free Public Schools.” Journal of Political Economy, vol. 90, no. 4, 1982. 


\section{FIGURE 1: CALIFORNIA - Four-year Colleges and Universities}

\begin{tabular}{|c|c|c|c|}
\hline Tuition & PUBLIC Institutions & PRIVATE Institutions & Tuition \\
\hline$\$ 3,248$ & $\begin{array}{l}\text { University of California - Berkeley } \\
\text { state aid }=\$ 10,364 / \text { student }\end{array}$ & $\begin{array}{l}25-800 \text { or ACT 30-26) } \\
\text { r Pupil = } \$ 21,571 \\
\text { California Institute of Technology } \\
\text { Stanford University } \\
\text { Harvey Mudd College } \\
\text { Pomona College } \\
\text { Claremont McKenna College }\end{array}$ & $\$ 15,767$ \\
\hline$\$ 2,903$ & $\begin{array}{r}\frac{\text { Highly Competitiv }}{\text { Student Expendi }} \\
\text { University of California }- \text { Los Angeles } \\
\text { state aid }=\$ 10,820 / \text { student }\end{array}$ & $\begin{array}{l}\text { 575-625 or ACT 28-29) } \\
\text { r Pupil }=\$ 17,438 \\
\text { None }\end{array}$ & ---- \\
\hline$\$ 2,448$ & $\begin{array}{c}\frac{\text { Very Competitive }}{\text { Student Expend }} \\
\text { University of California }- \text { San Diego } \\
\text { University of California - Davis } \\
\text { University of California - Irvine } \\
\text { and three others } \\
\text { state aid }=\$ 7,829 / \text { student }\end{array}$ & $\begin{array}{l}25-575 \text { or ACT } 25-27) \\
\text { er Pupil }=\$ 9,806 \\
\text { Thomas Aquinas College } \\
\text { Occidental College } \\
\text { Scripps College } \\
\quad \text { and ten others }\end{array}$ & $\$ 13,233$ \\
\hline$\$ 1,700$ & $\begin{array}{c}\text { Competitive (SA } \\
\text { Student Expend } \\
\text { Univ. of California - SantaBarbara } \\
\text { University of California - Riverside } \\
\text { California State Univ. - Bakersfield } \\
\text { California State Univ. - Fresno } \\
\text { California State Univ. - Long Beach } \\
\text { California State Univ. - Chico } \\
\text { and eight others } \\
\text { state aid }=\$ 5,704 \text { student }\end{array}$ & $\begin{array}{l}525 \text { or ACT 22-24) } \\
\text { er Pupil }=\$ 6,190 \\
\text { Saint Mary's College of CA } \\
\text { Christian Heritage College } \\
\text { Chapman University } \\
\text { University of the Pacific } \\
\text { Whittier College } \\
\text { Fresno Pacific College } \\
\quad \text { and fifteen others }\end{array}$ & $\$ 10,134$ \\
\hline$\$ 1,459$ & $\begin{array}{l}\text { Less Competitive (S } \\
\text { Student Expend } \\
\text { San Jose State University } \\
\text { California State Univ. - Stanislaus } \\
\text { California State Univ. - San Marcos } \\
\text { and four others } \\
\text { state aid }=\$ 6,496 / \text { student }\end{array}$ & $\begin{array}{l}\text { W } 450 \text { or ACT below 21) } \\
\text { er Pupil }=\$ 6,160 \\
\text { Samuel Merritt College } \\
\text { Cogswell College } \\
\text { West Coast University } \\
\text { and two others }\end{array}$ & $\$ 9,631$ \\
\hline---- & Student Expend & $\begin{array}{l}\text { titive } \\
\text { er Pupil }=\$ 3,908 \\
\text { Simpson College } \\
\text { Antioch University - Los Angeles } \\
\text { and fifteen others }\end{array}$ & $\$ 6,110$ \\
\hline
\end{tabular}

Sources: Barron's Educational Guides and 1991-92 IPEDS. Notes: Amounts are in 1992 dollars. State aid is appropriations divided by FTE students. Aid, tuition, and expenditures are reported as means for the group. 
FIGURE 2: MASSACHUSETTS - Four-year Colleges and Universities

\begin{tabular}{|c|c|c|c|}
\hline Tuition & PUBLIC Institutions & PRIVATE Institutions & Tuition \\
\hline ---- & $\begin{array}{l}\frac{\text { Most Competitiv }}{\text { Student Expen }} \\
\text { None }\end{array}$ & $\begin{array}{l}\text { 5-800 or ACT 30-26) } \\
\text { Pupil = \$16,685 } \\
\text { Harvard University } \\
\text { Amherst College } \\
\text { Massachusetts Institute of Tech. } \\
\quad \text { and three others }\end{array}$ & $\$ 17,271$ \\
\hline ---- & $\begin{array}{l}\frac{\text { Highly Competit }}{\text { Student Expen }} \\
\text { None }\end{array}$ & $\begin{array}{l}575-625 \text { or ACT 28-29) } \\
\text { Pupil }=\$ 11,432 \\
\text { Boston College } \\
\text { Worcester Polytechnic Institute } \\
\text { Tufts University } \\
\quad \text { and three others }\end{array}$ & $\$ 16,472$ \\
\hline---- & $\begin{array}{l}\text { Very Competiti } \\
\text { Student Expen } \\
\text { None }\end{array}$ & $\begin{array}{l}25-575 \text { or ACT 25-27) } \\
\text { r Pupil }=\$ 7,745 \\
\text { Brandeis University } \\
\text { Wheaton College } \\
\text { Babson College } \\
\quad \text { and seven others }\end{array}$ & $\$ 14,621$ \\
\hline$\$ 3,520$ & $\begin{array}{l}\text { Competitive } \\
\text { Student Exper } \\
\text { University of Mass. - Amherst } \\
\text { Framingham State College } \\
\text { Worcester State College } \\
\text { University of Mass. - Dartmouth } \\
\text { University of Mass. - Lowell } \\
\text { and four others } \\
\text { state aid }=\$ 3,039 \text { /student }\end{array}$ & $\begin{array}{l}25 \text { or ACT 22-24) } \\
\text { r Pupil }=\$ 5,380 \\
\text { Gordon College } \\
\text { Northeastern University } \\
\text { Eastern Nazarene College } \\
\text { Simmons College } \\
\text { Endicott College } \\
\quad \text { and eight others }\end{array}$ & $\$ 10,395$ \\
\hline$\$ 3,021$ & $\begin{array}{l}\frac{\text { Less Competitive }}{\text { Student Exper }} \\
\text { Fitchburg State College } \\
\text { Massachusetts Maritime Academy } \\
\text { Salem State College } \\
\text { state aid }=\$ 5,943 / \text { student }\end{array}$ & $\begin{array}{l}\text { W } 450 \text { or ACT below 21) } \\
\text { r Pupil }=\$ 5,420 \\
\text { Springfield College } \\
\text { Western New England College } \\
\text { Hebrew College } \\
\quad \text { and seven others }\end{array}$ & $\$ 10,180$ \\
\hline---- & Student Exper & $\begin{array}{l}\frac{\text { itive }}{r \text { Pupil }=\$ 5,627} \\
\text { Lasell College } \\
\text { Saint Hyacinth College } \\
\text { Bay Path College }\end{array}$ & $\$ 8,912$ \\
\hline
\end{tabular}

Sources: Barron's Educational Guides and 1991-92 IPEDS. Notes: Amounts are in 1992 dollars. State aid is appropriations divided by FTE students. Aid, tuition, and expenditures are reported as means for the group. 
FIGURE 3: In-Kind Subsidies to Public Institutions

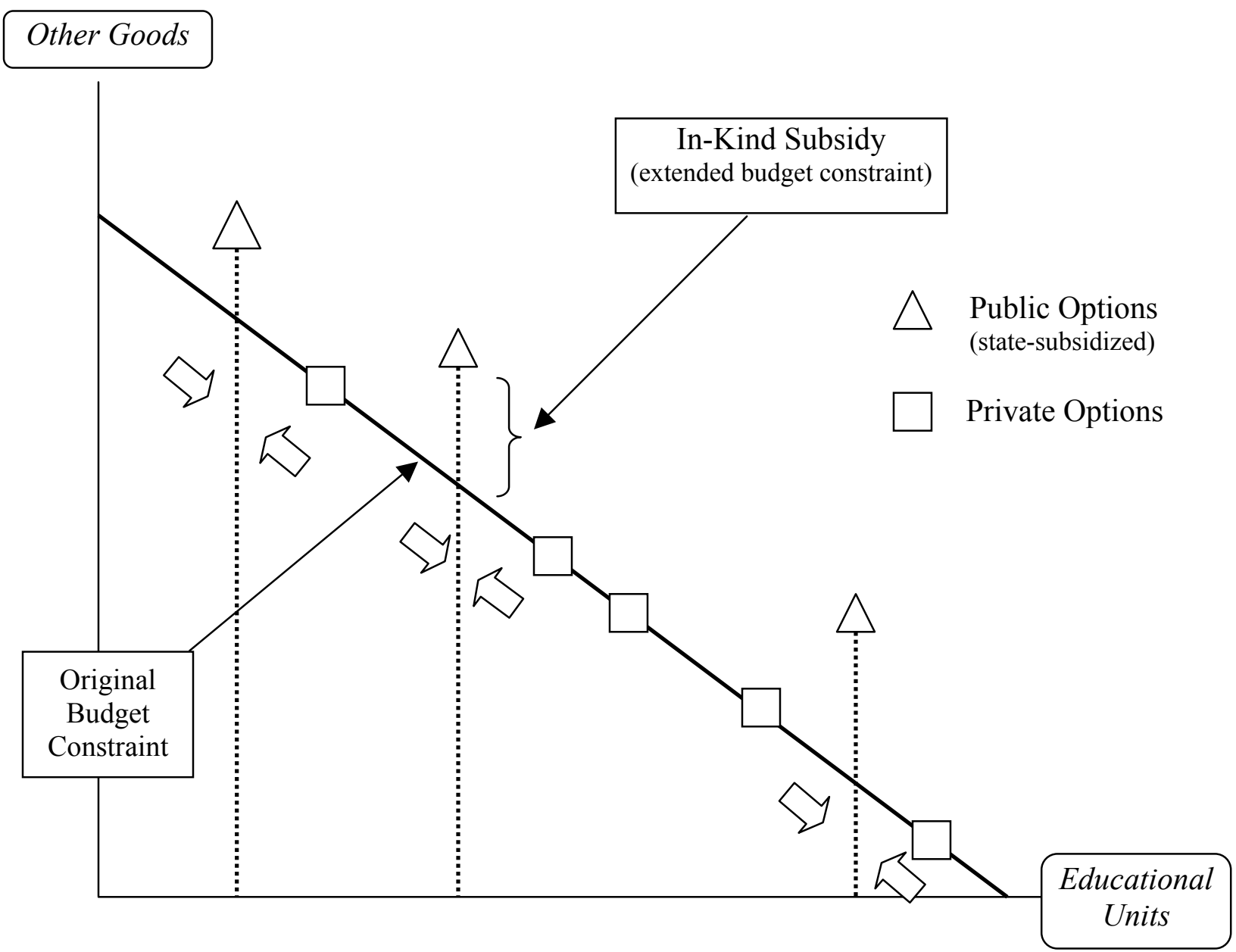


FIGURE 4: ILLINOIS - Four-year Colleges and Universities

\begin{tabular}{|c|c|c|c|}
\hline & Public Institutions & Private Institutions & \\
\hline--- & $\begin{array}{l}\text { Student Expen } \\
\text { None }\end{array}$ & $\begin{array}{l}\text { ive } \\
\text { pil }=\$ 24,511 \\
\text { Two }\end{array}$ & $\$ 16,226$ \\
\hline$\$ 3,458$ & $\begin{array}{c}\text { Student Exper } \\
\text { One } \\
\text { state aid }=\$ 7,373 / \text { student }\end{array}$ & $\begin{array}{l}\text { tive } \\
\text { upil }=\$ 7,707 \\
\text { Three }\end{array}$ & $\$ 11,857$ \\
\hline--- & $\begin{array}{l}\text { Student Exper } \\
\text { None }\end{array}$ & $\begin{array}{r}\frac{\text { ive }}{\text { upil }}=\$ 6,625 \\
\text { Seven }\end{array}$ & $\$ 11,489$ \\
\hline$\$ 2,672$ & $\begin{array}{c}\text { Student Exper } \\
\text { Seven } \\
\text { state aid }=\$ 4,172 / \text { student }\end{array}$ & $\begin{aligned} & \\
& \text { Twenty-eight }\end{aligned}$ & $\$ 9,108$ \\
\hline$\$ 2,013$ & $\begin{array}{l}\text { Les } \\
\text { Student Exper } \\
\text { Two } \\
\text { state aid }=\$ 3,575 / \text { student }\end{array}$ & $\begin{array}{r}\text { ive } \\
\text { Three }\end{array}$ & $\$ 9,536$ \\
\hline$\$ 2,035$ & $\begin{array}{c}\text { No } \\
\text { Student Exper } \\
\text { state aid }=\$ 3,426 / \text { student }\end{array}$ & $\begin{array}{l}\frac{\mathrm{ve}}{u p i l}=\$ 5,341 \\
\text { Nine }\end{array}$ & $\$ 6,285$ \\
\hline
\end{tabular}

See the notes to the next figure.

FIGURE 5: NEBRASKA - Four-year Colleges and Universities

\begin{tabular}{|c|c|c|c|}
\hline & Public Institutions & Private Institutions & \\
\hline-- & None & None & --- \\
\hline--- & Hig & itive & --- \\
\hline--- & $\begin{array}{l}\text { Student Expe } \\
\text { None }\end{array}$ & $\begin{array}{l}\frac{\text { ive }}{\text { ipil }}=\$ 18,182 \\
\text { One }\end{array}$ & $\$ 9,670$ \\
\hline$\$ 1,954$ & $\begin{array}{c}\text { Student Expe } \\
\text { Two } \\
\text { state aid }=\$ 4,172 / \text { student }\end{array}$ & $\begin{array}{r}\text { upil }=\$ 4,659 \\
\text { Seven }\end{array}$ & $\$ 7,439$ \\
\hline$\$ 1,467$ & $\begin{array}{c}\text { Le } \\
\text { Student Expe } \\
\text { One } \\
\text { state aid }=\$ 2,504 / \text { studen }\end{array}$ & $\begin{array}{r}\text { ive } \\
\text { upil }=\$ 4,226 \\
\text { Two }\end{array}$ & $\$ 8,450$ \\
\hline$\$ 1,615$ & $\begin{array}{r}\underline{\mathrm{N}} \\
\text { Student Expe } \\
\text { Three } \\
\text { state aid }=\$ 2,631 / \text { student }\end{array}$ & $\begin{aligned} & \text { up } \\
& \text { upil }=\$ 2,949 \\
& \text { Three }\end{aligned}$ & $\$ 3,063$ \\
\hline
\end{tabular}

Sources: Barron's Educational Guides and 1991-92 IPEDS. Notes: Amounts are in 1992 dollars. State aid is appropriations divided by FTE students. Aid, tuition, and expenditures are reported as means for the group. 
TABLE 1: Variable Descriptions and Summary Statistics

\begin{tabular}{|c|c|c|}
\hline Variable & Description & $\begin{array}{c}\text { Mean } \\
\text { (standard deviation) } \\
\end{array}$ \\
\hline \multicolumn{3}{|c|}{ A. Student Characteristics (NELS88) } \\
\hline Student SAT & $\begin{array}{l}\text { Student SAT, converted ACT score, or predicted SAT based } \\
\text { on high school GPA }\end{array}$ & $\begin{array}{l}878 \\
(212)\end{array}$ \\
\hline Student SAT percentile & SAT score transformed into a percentile & $\begin{array}{c}49 \\
(29)\end{array}$ \\
\hline High-Ability & $\begin{array}{l}\text { Dummy Variable for Students with SAT greater than or } \\
\text { equal to } 1100\end{array}$ & 0.152 \\
\hline Low-Income & $\begin{array}{l}\text { Dummy Variable for Students with a family income less } \\
\text { than } \$ 20,000 \text { in } 1991\end{array}$ & 0.201 \\
\hline \multicolumn{3}{|c|}{ B. College Characteristics (1991-92 IPEDS unless otherwise noted) } \\
\hline Student Expenditures & $\begin{array}{l}\text { Expenditures on instruction, academic support, and student } \\
\text { services per pupil (school resources) }\end{array}$ & $\begin{array}{l}\$ 4,452 \\
(3,516)\end{array}$ \\
\hline School SAT & $\begin{array}{l}\text { Median student body SAT score (peer resources) (Barron's } \\
\quad \text { Profiles of American Colleges) }\end{array}$ & $\begin{array}{l}835 \\
(153)\end{array}$ \\
\hline School SAT percentile & Median student body SAT transformed into a percentile & $\begin{array}{c}43 \\
(23)\end{array}$ \\
\hline FTE Enrollment & Full-time Equivalent Undergraduate Enrollment in 1991-92 & $\begin{array}{c}3,304 \\
(4,389)\end{array}$ \\
\hline Student-Faculty Ratio & $\begin{array}{l}\text { FTE Undergraduate Enrollment divided by FTE Faculty } \\
\text { (Source: American Survey of Colleges, 1991-92) }\end{array}$ & $\begin{array}{l}15.2 \\
(4.6)\end{array}$ \\
\hline $\begin{array}{l}\text { Percent of Faculty } \\
\text { with a Ph.D. }\end{array}$ & $\begin{array}{l}\text { Percent of faculty with a Ph.D. or other terminal (Source: } \\
\text { American Survey of Colleges, 1991-92) }\end{array}$ & $\begin{array}{c}31.4 \\
(26.1)\end{array}$ \\
\hline $\begin{array}{l}\text { College } \\
\text { Competitiveness }\end{array}$ & $\begin{array}{l}\text { Groupings based on student test scores, high school rank, } \\
\text { and college acceptance rate (Source: Barron's Guide) }\end{array}$ & --- \\
\hline Two-year & Dummy Variable for Two-year colleges & 0.430 \\
\hline Public & Dummy Variable for Public colleges & 0.538 \\
\hline \multicolumn{3}{|c|}{ C. Match-Specific Variables (Interacting Student Characteristics with College Characteristics) } \\
\hline List Tuition Price & $\begin{array}{l}\text { In-state tuition if a resident of the state; Out-of-State tuition } \\
\text { if not }\end{array}$ & $\begin{array}{l}\$ 6,202 \\
(3,684)\end{array}$ \\
\hline Distance & $\begin{array}{l}\text { The number of miles between the student's high school and } \\
\text { the college based off zip codes }\end{array}$ & $\begin{array}{l}1,031 \\
(725)\end{array}$ \\
\hline $\begin{array}{l}\text { SAT Difference: Student } \\
\text { \%tile higher }\end{array}$ & $\begin{array}{l}\text { Equal to the difference in SAT percentiles if the student's } \\
\text { SAT is greater than the school's }\end{array}$ & $\begin{array}{c}18.4 \\
(22.9)\end{array}$ \\
\hline $\begin{array}{l}\text { SAT Difference: School } \\
\text { \%tile higher }\end{array}$ & $\begin{array}{l}\text { Equal to the difference in SAT percentiles if the school's } \\
\text { median SAT is greater than the student's }\end{array}$ & $\begin{array}{c}12.3 \\
(19.7)\end{array}$ \\
\hline
\end{tabular}


TABLE 2: Conditional Logistic Estimation of the Decisions between Colleges Marginal Effect on the Probability of Enrollment (z-statistics in parentheses) Dependent Variable: Attended College $j$ within Two Years of Graduation

\begin{tabular}{|c|c|c|c|c|}
\hline & (1) & (2) & $\begin{array}{l}\text { Low-Income } \\
\text { Interactions }\end{array}$ & $\begin{array}{c}\text { High SAT } \\
\text { Interactions } \\
\end{array}$ \\
\hline \multicolumn{5}{|l|}{ College Costs } \\
\hline $\begin{array}{l}\text { Tuition Price net Pell } \\
\quad(\text { per } \$ 1,000)\end{array}$ & $\begin{array}{l}-.3930 \\
(42.92)\end{array}$ & $\begin{array}{l}-.4054 \\
(35.63)\end{array}$ & $\begin{array}{l}-.0066 \\
(0.20)\end{array}$ & $\begin{array}{l}.0819 \\
(2.96)\end{array}$ \\
\hline $\begin{array}{l}\text { Tuition Squared } \\
\left(\text { per } \$ 1,000^{2}\right)\end{array}$ & $\begin{array}{l}.0186 \\
(36.60)\end{array}$ & $\begin{array}{l}.0193 \\
(28.66)\end{array}$ & $\begin{array}{l}.0033 \\
(1.85)\end{array}$ & $\begin{array}{l}-.0036 \\
(3.29)\end{array}$ \\
\hline $\begin{array}{l}\text { Distance } \\
\quad \text { (per } 100 \text { miles) }\end{array}$ & $\begin{array}{l}-.8099 \\
(81.06)\end{array}$ & $\begin{array}{l}-.8133 \\
(76.55)\end{array}$ & $\begin{array}{l}-.3461 \\
(9.78)\end{array}$ & $\begin{array}{c}.4479 \\
(13.07)\end{array}$ \\
\hline $\begin{array}{l}\text { Distance Squared } \\
\text { (per } 100^{2} \text { miles) }\end{array}$ & $\begin{array}{l}.1206 \\
(45.25)\end{array}$ & $\begin{array}{l}.1175 \\
(45.83)\end{array}$ & $\begin{array}{l}.0190 \\
(10.31)\end{array}$ & $\begin{array}{l}-.0135 \\
(10.12)\end{array}$ \\
\hline \multicolumn{5}{|l|}{ College Quality and Size } \\
\hline $\begin{array}{l}\text { Student Expenditures } \\
\quad(\text { per } \$ 1,000)\end{array}$ & $\begin{array}{l}.0425 \\
(2.67)\end{array}$ & $\begin{array}{l}.0825 \\
(3.77)\end{array}$ & & $\begin{array}{l}.1451 \\
(4.45)\end{array}$ \\
\hline $\begin{array}{l}\text { Student Exp. Squared } \\
\quad\left(\text { per } \$ 1,000^{2}\right)\end{array}$ & $\begin{array}{l}-.0005 \\
(1.03)\end{array}$ & $\begin{array}{l}-.0047 \\
(5.40)\end{array}$ & & $\begin{array}{l}.0012 \\
(1.09)\end{array}$ \\
\hline $\begin{array}{l}\text { Student-Faculty } \\
\text { Ratio }\end{array}$ & $\begin{array}{l}.0106 \\
(2.49)\end{array}$ & $\begin{array}{l}.0117 \\
(2.73)\end{array}$ & & \\
\hline $\begin{array}{l}\text { Percent of Faculty with } \\
\text { Ph.D. (per } 10 \text { pts) }\end{array}$ & $\begin{array}{l}.0056 \\
(5.75)\end{array}$ & $\begin{array}{l}.0053 \\
(5.46)\end{array}$ & & \\
\hline $\begin{array}{l}\text { FTE Enrollment } \\
\text { (per } 1,000)\end{array}$ & $\begin{array}{l}.1549 \\
(33.20)\end{array}$ & $\begin{array}{l}.1548 \\
(32.99)\end{array}$ & & \\
\hline \multicolumn{5}{|l|}{ Student-College Match } \\
\hline $\begin{array}{l}\text { Student \%tile larger } \\
\text { (per } 10 \mathrm{pts})\end{array}$ & $\begin{array}{l}-.2883 \\
(11.45)\end{array}$ & $\begin{array}{c}-.2822 \\
(10.81)\end{array}$ & & \\
\hline $\begin{array}{l}\text { Student larger Squared } \\
\left.\text { (per } 10^{2} \mathrm{pts}\right)\end{array}$ & $\begin{array}{l}-.0124 \\
(2.83)\end{array}$ & $\begin{array}{l}-.0048 \\
(1.00)\end{array}$ & & \\
\hline $\begin{array}{l}\text { School \%tile larger } \\
\quad \text { (per } 10 \text { pts) }\end{array}$ & $\begin{array}{l}.1916 \\
(5.03)\end{array}$ & $\begin{array}{l}.2872 \\
(7.04)\end{array}$ & & \\
\hline $\begin{array}{l}\text { School larger Squared } \\
\text { (per } 10^{2} \text { pts) }\end{array}$ & $\begin{array}{l}-.2883 \\
(9.28)\end{array}$ & $\begin{array}{l}-.0569 \\
(9.99)\end{array}$ & & \\
\hline \multicolumn{5}{|l|}{ Two-year Colleges } \\
\hline $\begin{array}{l}\text { Two-Year College } \\
\text { Dummy Variable }\end{array}$ & $\begin{array}{l}.3800 \\
(4.99)\end{array}$ & $\begin{array}{l}.3152 \\
(4.16)\end{array}$ & & \\
\hline Strata (individuals) & 5,683 & 5,683 & & \\
\hline N (combinations) & $15,167,927$ & $15,167,927$ & & \\
\hline Pseudo R-squared & .3999 & .4080 & & \\
\hline
\end{tabular}

Sources: NELS88 individual data and 1991-92 IPEDS college data.

Notes: Sample includes only those who attended college. Marginal effects are interpreted as the percentage by which the probability favoring attendance at college $j$ is affected with a one-unit increase in that variable. Monetary amounts are in 1992 dollars. Tuition is defined as list tuition price net the student's expected federal Pell Grant (based on income). Student expenditures are defined as instruction, academic support and student services. FTE Enrollment is for undergraduates in 1991. Low income is defined as a family income below $\$ 20,000$ in 1991 . HighSAT is defined as scoring 1100 or above. The model also includes: cubic distance and FTE enrollment squared. 
TABLE 3: Logistic Estimation of the College Enrollment Decision Marginal Effect on the Probability of Enrollment (z-statistics in parentheses) Dependent Variable: Attended Any College within Two Years of Graduation

\begin{tabular}{|c|c|c|c|c|}
\hline & $\begin{array}{c}\text { (1) } \\
\text { Closest Two-year } \\
\text { Public College }\end{array}$ & $\begin{array}{l}\text { (2) } \\
\text { Closest Four-year } \\
\text { Public College }\end{array}$ & $\begin{array}{c}\text { Predicted } \\
\text { Main } \\
\text { Effect } \\
\end{array}$ & $\begin{array}{l}\text { ege Choice } \\
\text { Two-Year } \\
\text { Interaction }\end{array}$ \\
\hline $\begin{array}{l}\text { Tuition Price } \\
\quad(\text { per } \$ 1,000)\end{array}$ & $\begin{array}{l}.0060 \\
(0.14)\end{array}$ & $\begin{array}{l}-.0010 \\
(0.02)\end{array}$ & $\begin{array}{c}-.0776^{* *} \\
(2.23)\end{array}$ & $\begin{array}{l}.0355 \\
(0.56)\end{array}$ \\
\hline $\begin{array}{l}\text { Tuition Squared } \\
\quad\left(\text { per } \$ 1,000^{2}\right)\end{array}$ & $\begin{array}{l}-.0059 \\
(0.94)\end{array}$ & $\begin{array}{l}-.0035 \\
(0.62)\end{array}$ & $\begin{array}{l}.0085^{* *} \\
(3.74)\end{array}$ & \\
\hline $\begin{array}{l}\text { Distance } \\
\quad \text { (per } 100 \text { miles) }\end{array}$ & $\begin{array}{c}-.4463^{* *} \\
(3.88)\end{array}$ & $\begin{array}{l}-.1186 \\
(0.88)\end{array}$ & $\begin{array}{c}-.1930^{* *} \\
(2.08)\end{array}$ & $\begin{array}{l}.3696 \\
(1.35)\end{array}$ \\
\hline $\begin{array}{r}\text { Distance Squared } \\
\left(\text { per } 100^{2} \text { miles }\right)\end{array}$ & $\begin{array}{c}.0702 * * \\
(2.57)\end{array}$ & $\begin{array}{l}.0039 \\
(0.16)\end{array}$ & $\begin{array}{l}.0060 \\
(1.34)\end{array}$ & \\
\hline $\begin{array}{l}\text { Student SAT percentile } \\
\quad \text { (per } 10 \mathrm{pts})\end{array}$ & $\begin{array}{c}.0037^{* *} \\
(3.14)\end{array}$ & & & \\
\hline $\begin{array}{l}\text { Student \%tile larger } \\
\quad \text { (per } 10 \text { pts) }\end{array}$ & & $\begin{array}{c}-.1216^{* *} \\
(4.55)\end{array}$ & $\begin{array}{c}-.0908^{* *} \\
(2.05)\end{array}$ & \\
\hline $\begin{array}{l}\text { School \%tile larger } \\
\text { (per } 10 \text { pts) }\end{array}$ & & $\begin{array}{c}-.0888^{* *} \\
(6.15)\end{array}$ & $\begin{array}{c}-.0425^{* *} \\
(2.00)\end{array}$ & \\
\hline $\begin{array}{l}\text { FTE Enrollment } \\
\text { (per } 1,000)\end{array}$ & $\begin{array}{l}-.0080 \\
(0.64)\end{array}$ & $\begin{array}{l}-.0117 \\
(1.46)\end{array}$ & $\begin{array}{l}.0107 \\
(0.95)\end{array}$ & $\begin{array}{r}-.0096 \\
(1.01)\end{array}$ \\
\hline $\begin{array}{l}\text { FTE Enrollment Squared } \\
\quad\left(\text { per } 1,000^{2}\right)\end{array}$ & $\begin{array}{l}-.0003 \\
(0.68)\end{array}$ & $\begin{array}{l}.0003 \\
(1.46)\end{array}$ & $\begin{array}{l}-.0003 \\
(1.12)\end{array}$ & \\
\hline $\begin{array}{l}\text { Public, Two-year } \\
\text { Dummy }\end{array}$ & & & $\begin{array}{c}-.3179 * * \\
(2.50)\end{array}$ & \\
\hline $\begin{array}{l}\text { County Unemployment } \\
\text { Rate (1992) }\end{array}$ & $\begin{array}{l}.0156 \\
(1.50)\end{array}$ & $\begin{array}{l}.0150 \\
(1.42)\end{array}$ & $\begin{array}{l}.0174 \\
(1.63)\end{array}$ & \\
\hline Pseudo R-squared & 5,661 & 5,661 & 5,661 & --- \\
\hline Observations & .0479 & .0500 & .0522 & --- \\
\hline
\end{tabular}

** Significant at the 5\% level * Significant at the $10 \%$ level

Sources: NELS88 individual data and 1991-92 IPEDS college data.

Notes: Marginal effects are interpreted as the percentage by which the probability favoring attendance at any college is affected with a one-unit increase in that variable. Figures are in 1992 dollars. FTE Enrollment is for undergraduates in 1991. All regressions include the following controls: gender, race (Black, Hispanic, Asian, Native American), 1991 family income, parents' education, private high school dummy, and a dummy for completing the GED. The predicted college choice (specification 3 ) is determined by the conditional logistic model in Table 2, specification 2. The predicted college choice is the closest public, two-year college for $14.1 \%$ and the closest public, four-year college for $35.6 \%$ of the sample. Of the remaining colleges, 74.9 percent are public, fouryear colleges, 14.0 percent are public, two-year colleges, and 11.1 percent are private, four-year colleges. 
TABLE 4: Comparing Actual to Predicted College Investments (means reported)

\begin{tabular}{|c|c|c|c|c|}
\hline & \multicolumn{2}{|c|}{ Actual College Choices } & \multicolumn{2}{|c|}{ Predicted Choices } \\
\hline & $\begin{array}{l}\text { Four-Year } \\
\text { Colleges }\end{array}$ & $\begin{array}{c}\text { Two-Year } \\
\text { Colleges }\end{array}$ & $\begin{array}{l}\text { Four-Year } \\
\text { Colleges }\end{array}$ & $\begin{array}{c}\text { Two-Year } \\
\text { Colleges }\end{array}$ \\
\hline \multicolumn{5}{|l|}{ A. The Whole Sample } \\
\hline $\begin{array}{l}\text { Attended or } \\
\text { Predicted to Attend }\end{array}$ & 3,841 & 1,842 & 3,829 & 1,857 \\
\hline Number to Publics & $2,547(66 \%)$ & $1,764(96 \%)$ & $2,706(71 \%)$ & $1,749(94 \%)$ \\
\hline List Tuition & $\$ 5,863$ & $\$ 1,621$ & $\$ 5,634$ & $\$ 2,030$ \\
\hline Distance (miles) & 231 & 89 & 188 & 181 \\
\hline Student Expenditures & $\$ 7,466$ & $\$ 3,388$ & $\$ 7,422$ & $\$ 3,487$ \\
\hline SAT Percentile & 67.60 & --- & 67.61 & --- \\
\hline \multicolumn{5}{|c|}{ B. High-Ability Students $(S A T \geq 1100)$} \\
\hline $\begin{array}{l}\text { Attended or } \\
\text { Predicted to Attend }\end{array}$ & 966 & 109 & 980 & 107 \\
\hline Number to Publics & $506(52 \%)$ & $107(98 \%)$ & $539(55 \%)$ & $100(93 \%)$ \\
\hline List Tuition & $\$ 8,600$ & $\$ 1,563$ & $\$ 8,484$ & $\$ 2,261$ \\
\hline Distance (miles) & 337 & 117 & 311 & 344 \\
\hline Student Expenditures & $\$ 10,492$ & $\$ 3,407$ & $\$ 10,643$ & $\$ 3,749$ \\
\hline SAT Percentile & 79.79 & --- & 78.17 & --- \\
\hline \multicolumn{5}{|c|}{ C. Low-Income Students (family income below $\$ 20,000$ in 1991) } \\
\hline $\begin{array}{l}\text { Attended or } \\
\text { Predicted to Attend }\end{array}$ & 507 & 370 & 542 & 373 \\
\hline Number to Publics & $377(74 \%)$ & $356(96 \%)$ & $434(80 \%)$ & $352(94 \%)$ \\
\hline List Tuition & $\$ 4,335$ & $\$ 1,476$ & $\$ 4,004$ & $\$ 1,970$ \\
\hline Distance (miles) & 181 & 86 & 139 & 159 \\
\hline Student Expenditures & $\$ 6,396$ & $\$ 3,445$ & $\$ 6,315$ & $\$ 3,440$ \\
\hline SAT Percentile & 59.84 & --- & 62.20 & --- \\
\hline
\end{tabular}

Sources: NELS88 individual data and 1991-92 IPEDS college data.

Notes: Colleges were weighted by: (1) the relative odds of that person choosing that college (calculated from Table 2, specification 2), and (2) the individual likelihood of attendance (calculated from Table 3, specification 3). Figures are in 1992 dollars. List tuition is the in-state price if the student attended high school in that state; otherwise it is the out-of-state price. Student expenditures are funds for instruction, academic support and student services. 
TABLE 5: State Simulations - Predicted Choices as a Resident of each State (means reported)

\begin{tabular}{|c|c|c|c|c|}
\hline $\begin{array}{l}\text { State Subsidy Level } \\
\text { Public College Quality }\end{array}$ & $\begin{array}{c}\text { CALIFORNIA } \\
\text { High } \\
\text { Much variation }\end{array}$ & $\begin{array}{c}\text { ILLINOIS } \\
\text { Medium } \\
\text { Some variation }\end{array}$ & $\begin{array}{l}\text { NEBRASKA } \\
\text { Medium } \\
\text { Little variation }\end{array}$ & $\begin{array}{c}\text { MASSACHUSETTS } \\
\text { Low } \\
\text { Little variation }\end{array}$ \\
\hline \multicolumn{5}{|l|}{ A. The Whole Sample } \\
\hline Total Predicted to Attend & 5,785 & 5,692 & 5,768 & 5,731 \\
\hline \multicolumn{5}{|l|}{ Four-year Colleges } \\
\hline Predicted to Attend & 3,377 & 3,718 & 4,367 & 3,903 \\
\hline Number to Publics & $3,110(92 \%)$ & $2,529(68 \%)$ & $3,329(76 \%)$ & $2,293(59 \%)$ \\
\hline List Tuition & $\$ 2,826$ & $\$ 5,781$ & $\$ 4,065$ & $\$ 8,252$ \\
\hline Student Expenditures & $\$ 9,244$ & $\$ 7,369$ & $\$ 5,759$ & $\$ 8,085$ \\
\hline SAT Percentile & 68.74 & 65.41 & 60.22 & 67.73 \\
\hline \multicolumn{5}{|l|}{ Two-year Colleges } \\
\hline Predicted to Attend & 2,408 & 1,974 & 1,401 & 1,828 \\
\hline Number to Publics & $2,367(98 \%)$ & $1,852(94 \%)$ & $1,339(96 \%)$ & $1,629(89 \%)$ \\
\hline List Tuition & $\$ 405$ & $\$ 3,038$ & $\$ 2,194$ & $\$ 3,199$ \\
\hline \multicolumn{5}{|c|}{ B. High-Ability Students (SAT $\geq 1100)$} \\
\hline Total Predicted to Attend & 1,088 & 1,079 & 1,072 & 1,111 \\
\hline \multicolumn{5}{|l|}{ Four-year Colleges } \\
\hline Predicted to Attend & 978 & 967 & 948 & 1,025 \\
\hline Number to Publics & $880(90 \%)$ & $558(58 \%)$ & $605(64 \%)$ & $330(32 \%)$ \\
\hline List Tuition & $\$ 3,755$ & $\$ 7,946$ & $\$ 6,302$ & $\$ 11,991$ \\
\hline Student Expenditures & $\$ 12,759$ & $\$ 10,448$ & $\$ 8,149$ & $\$ 12,979$ \\
\hline SAT Percentile & 80.22 & 75.04 & 68.29 & 80.86 \\
\hline \multicolumn{5}{|l|}{ Two-year Colleges } \\
\hline Predicted to Attend & 110 & 112 & 124 & 86 \\
\hline Number to Publics & $105(96 \%)$ & $104(93 \%)$ & $116(93 \%)$ & $75(88 \%)$ \\
\hline List Tuition & $\$ 670$ & $\$ 3,132$ & $\$ 2,627$ & $\$ 3,400$ \\
\hline \multicolumn{5}{|c|}{ C. Low-Income Students (Family income below $\$ 20,000$ in 1991) } \\
\hline Total Predicted to Attend & 945 & 918 & 938 & 934 \\
\hline \multicolumn{5}{|l|}{ Four-year Colleges } \\
\hline Predicted to Attend & 525 & 503 & 676 & 544 \\
\hline Number to Publics & $481(92 \%)$ & $367(73 \%)$ & $525(78 \%)$ & $380(70 \%)$ \\
\hline List Tuition & $\$ 2,721$ & $\$ 4,938$ & $\$ 3,356$ & $\$ 6,875$ \\
\hline Student Expenditures & $\$ 8,688$ & $\$ 6,838$ & $\$ 5,240$ & $\$ 6,870$ \\
\hline SAT Percentile & 67.38 & 62.57 & 57.72 & 62.92 \\
\hline \multicolumn{5}{|l|}{ Two-year Colleges } \\
\hline Predicted to Attend & 420 & 415 & 262 & 390 \\
\hline Number to Publics & $408(97 \%)$ & $391(94 \%)$ & $252(96 \%)$ & $350(90 \%)$ \\
\hline List Tuition & $\$ 545$ & $\$ 3,080$ & $\$ 2,130$ & $\$ 3,173$ \\
\hline
\end{tabular}

Sources: NELS88 individual data and 1991-92 IPEDS college data.

Notes: Colleges were weighted by: (1) the relative odds of that person choosing that college (calculated from Table 2, specification 2), and (2) the individual likelihood of attendance (calculated from Table 3, specification 3).

Figures are in 1992 dollars. List tuition is the in-state price if the student attended high school in that state; otherwise it is the out-of-state price. Student expenditures are funds for instruction, academic support and student services. 
TABLE 6: Mean Voucher and Tuition Price under Different Aid Schemes

\begin{tabular}{|c|c|c|c|c|c|c|}
\hline \multirow{3}{*}{ Voucher Details } & \multirow{2}{*}{$\begin{array}{c}\text { In-kind } \\
\text { Subsidy } \\
\text { Current system }\end{array}$} & \multicolumn{2}{|c|}{$\begin{array}{c}\text { Voucher to } \\
\text { In-State Public Colleges }\end{array}$} & \multicolumn{2}{|c|}{$\begin{array}{l}\text { Voucher to any } \\
\text { In-State College }\end{array}$} & \multirow{2}{*}{$\begin{array}{c}\text { No State } \\
\text { Support } \\
\text { None }\end{array}$} \\
\hline & & $2 y r=4 y r$ & $2 y r=1 / 24 y r$ & $2 y r=4 y r$ & $2 y r=1 / 24 y r$ & \\
\hline & $(1)$ & (2) & (3) & (4) & (5) & (6) \\
\hline \multicolumn{7}{|l|}{ A. Mean State Voucher } \\
\hline Four-years Colleges & None & $\begin{array}{l}3,344 \\
(555)\end{array}$ & $\begin{array}{l}4,227 \\
(702)\end{array}$ & $\begin{array}{l}2,603 \\
(567)\end{array}$ & $\begin{array}{l}3,167 \\
(769)\end{array}$ & None \\
\hline Two-years Colleges & None & $\begin{array}{l}3,344 \\
(555)\end{array}$ & $\begin{array}{l}2,114 \\
(351)\end{array}$ & $\begin{array}{l}2,603 \\
(567)\end{array}$ & $\begin{array}{l}1,583 \\
(384)\end{array}$ & None \\
\hline \multicolumn{7}{|c|}{$\begin{array}{l}\text { B. Mean Tuition Price - Public Colleges } \\
\text { Public Four-years }\end{array}$} \\
\hline $\begin{array}{l}\text { Most, Highly, and } \\
\text { Very Competitive }\end{array}$ & $\begin{array}{c}2,821 \\
(1,100)\end{array}$ & $\begin{array}{c}5,656 \\
(3,280)\end{array}$ & $\begin{array}{c}4,694 \\
(3,225)\end{array}$ & $\begin{array}{c}6,432 \\
(3,280)\end{array}$ & $\begin{array}{c}5,823 \\
(3,262)\end{array}$ & $\begin{array}{c}9,038 \\
(3,281)\end{array}$ \\
\hline Competitive & $\begin{array}{l}2,291 \\
(814)\end{array}$ & $\begin{array}{c}3,341 \\
(2,278)\end{array}$ & $\begin{array}{c}2,491 \\
(2,252)\end{array}$ & $\begin{array}{c}4,073 \\
(2,389)\end{array}$ & $\begin{array}{l}3,517 \\
(2,444)\end{array}$ & $\begin{array}{c}6,672 \\
(2,271)\end{array}$ \\
\hline Less Competitive & $\begin{array}{l}1,982 \\
(790)\end{array}$ & $\begin{array}{c}2,346 \\
(1,621)\end{array}$ & $\begin{array}{c}1,546 \\
(1,616)\end{array}$ & $\begin{array}{c}2,988 \\
(1,747)\end{array}$ & $\begin{array}{c}2,415 \\
(1,830)\end{array}$ & $\begin{array}{c}5,774 \\
(1,566)\end{array}$ \\
\hline Noncompetitive & $\begin{array}{c}2,720 \\
(1,326)\end{array}$ & $\begin{array}{c}2,280 \\
(1,601)\end{array}$ & $\begin{array}{c}1,718 \\
(1,510)\end{array}$ & $\begin{array}{c}3,081 \\
(1,777)\end{array}$ & $\begin{array}{c}2,728 \\
(1,797)\end{array}$ & $\begin{array}{c}5,447 \\
(1,605)\end{array}$ \\
\hline \multicolumn{7}{|l|}{ Public Two-years } \\
\hline Noncompetitive & $\begin{array}{l}1,260 \\
(961)\end{array}$ & $\begin{array}{c}419 \\
(1,045)\end{array}$ & $\begin{array}{c}1,067 \\
(1,339)\end{array}$ & $\begin{array}{c}759 \\
(1,286)\end{array}$ & $\begin{array}{c}1,478 \\
(1,484)\end{array}$ & $\begin{array}{c}3,041 \\
(1,494)\end{array}$ \\
\hline \multicolumn{7}{|c|}{$\begin{array}{l}\text { C. Mean Tuition Price - Private Colleges } \\
\text { Private Four-years }\end{array}$} \\
\hline $\begin{array}{l}\text { Most, Highly, and } \\
\text { Very Competitive }\end{array}$ & $\begin{array}{l}13,161 \\
(3,686)\end{array}$ & \multirow{4}{*}{$\begin{array}{l}\text { Same as the } \\
\text { current } \\
\text { in-kind aid } \\
\text { system } \\
\text { for all } \\
\text { private } \\
\text { colleges }\end{array}$} & \multirow{4}{*}{$\begin{array}{c}\text { Same as the } \\
\text { current } \\
\text { in-kind aid } \\
\text { system } \\
\text { for all } \\
\text { private } \\
\text { colleges }\end{array}$} & $\begin{array}{l}10,727 \\
(3,816)\end{array}$ & $\begin{array}{l}10,223 \\
(3,868)\end{array}$ & \multirow{6}{*}{$\begin{array}{c}\text { Same as the } \\
\text { current } \\
\text { in-kind aid } \\
\text { system } \\
\text { for all } \\
\text { private } \\
\text { colleges }\end{array}$} \\
\hline Competitive & $\begin{array}{c}9,204 \\
(2,320)\end{array}$ & & & $\begin{array}{c}6,705 \\
(2,515)\end{array}$ & $\begin{array}{c}6,202 \\
(2,571)\end{array}$ & \\
\hline Less Competitive & $\begin{array}{c}7,562 \\
(2,356)\end{array}$ & & & $\begin{array}{c}4,979 \\
(2,594)\end{array}$ & $\begin{array}{c}4,464 \\
(2,684)\end{array}$ & \\
\hline Noncompetitive & $\begin{array}{c}5,714 \\
(2,391)\end{array}$ & & & $\begin{array}{c}3,063 \\
(2,517)\end{array}$ & $\begin{array}{c}2,519 \\
(2,497)\end{array}$ & \\
\hline \multicolumn{6}{|l|}{ Private Two-years } & \\
\hline Noncompetitive & $\begin{array}{c}6,164 \\
(2,161)\end{array}$ & & & $\begin{array}{l}3,727 \\
(2,254)\end{array}$ & $\begin{array}{c}4,692 \\
(2,216)\end{array}$ & \\
\hline
\end{tabular}

Source: 1991-92 IPEDS college data and college groupings from the Barron's Profiles of American Colleges.

Notes: Figures are in 1992 dollars. Where applicable, the tuition price is adjusted for the loss of state appropriations per FTE student minus any voucher. The voucher value was calculated as the total state appropriations for nonspecialized colleges divided by the FTE number of students attending these colleges (for simulations 2 and 3 , only students attending public colleges were counted). In the simulations in which the four-year voucher is twice as large as the two-year voucher (simulations 3 and 5), 70 percent of students are assumed to attend four-year schools. Given the distribution of different types and levels of colleges across states with different levels of support, the mean values do not reflect the simple subtraction of the voucher amount from the unsubsidized cost. 
TABLE 7: Predicted College Investments under Different Aid Schemes

\begin{tabular}{|c|c|c|c|c|c|c|}
\hline \multirow[b]{2}{*}{ Voucher Details } & \multirow{2}{*}{$\begin{array}{l}\text { In-kind Subsidy } \\
\text { Current system } \\
\text { (1) }\end{array}$} & \multicolumn{2}{|c|}{$\begin{array}{c}\text { Voucher to any } \\
\text { In-State Public College }\end{array}$} & \multicolumn{2}{|c|}{$\begin{array}{l}\text { Voucher to any } \\
\text { In-State College }\end{array}$} & \multirow{2}{*}{$\begin{array}{c}\text { No State Support } \\
\text { None } \\
(6) \\
\end{array}$} \\
\hline & & $\begin{array}{c}2 y r=4 y r \\
(2)\end{array}$ & $\begin{array}{c}2 y r=1 / 24 y r \\
(3)\end{array}$ & $\begin{array}{c}2 y r=4 y r \\
(4)\end{array}$ & $\begin{array}{c}2 y r=1 / 24 y r \\
(5)\end{array}$ & \\
\hline \multicolumn{7}{|l|}{ A. The Whole Sample } \\
\hline Total Enrollment & 5,686 & 5,643 & 5,702 & 5,611 & 5,664 & 5,535 \\
\hline \multicolumn{7}{|l|}{ Four-year Colleges } \\
\hline Predicted to Enroll & 3,829 & 3,370 & 3,749 & 3,396 & 3,766 & 3,414 \\
\hline No. to Publics & $2,706(71 \%)$ & $2,371(70 \%)$ & $2,778(74 \%)$ & $2,050(60 \%)$ & $2,321(62 \%)$ & $1,925(56 \%)$ \\
\hline Tuition Price & $\$ 5,634$ & $\$ 5,723$ & $\$ 4,953$ & $\$ 5,840$ & $\$ 5,272$ & $\$ 7,956$ \\
\hline Expenditures & $\$ 7,422$ & $\$ 6,814$ & $\$ 6,642$ & $\$ 6,802$ & $\$ 6,643$ & $\$ 7,245$ \\
\hline SAT percentile & 67.61 & 64.95 & 64.52 & 64.61 & 64.07 & 66.22 \\
\hline \multicolumn{7}{|l|}{ Two-year Colleges } \\
\hline Predicted to Enroll & 1,857 & 2,273 & 1,953 & 2,215 & 1,898 & 2,121 \\
\hline No. to Publics & $1,749(94 \%)$ & $2,161(95 \%)$ & $1,840(94 \%)$ & $2,033(92 \%)$ & $1,744(92 \%)$ & $1,943(92 \%)$ \\
\hline Tuition Price & $\$ 2,030$ & $\$ 1,666$ & $\$ 2,095$ & $\$ 1,833$ & $\$ 2,332$ & $\$ 3,328$ \\
\hline \multicolumn{7}{|c|}{ B. High-Ability Students $(S A T \geq 1100)$} \\
\hline Total Enrollment & 1,087 & 1,085 & 1,083 & 1,084 & 1,084 & 1,096 \\
\hline \multicolumn{7}{|l|}{ Four-year Colleges } \\
\hline Predicted to Enroll & 980 & 921 & 948 & 924 & 951 & 954 \\
\hline No. to Publics & $539(55 \%)$ & $503(55 \%)$ & $551(58 \%)$ & $455(49 \%)$ & $480(50 \%)$ & $431(45 \%)$ \\
\hline Tuition Price & $\$ 8,484$ & $\$ 8,663$ & $\$ 7,938$ & $\$ 8,621$ & $\$ 8,125$ & $\$ 10,407$ \\
\hline Expenditures & $\$ 10,643$ & $\$ 9,915$ & $\$ 9,629$ & $\$ 9,973$ & $\$ 9,787$ & $\$ 10,688$ \\
\hline SAT percentile & 78.17 & 75.44 & 74.87 & 75.44 & 75 & 77.17 \\
\hline \multicolumn{7}{|l|}{ Two-year Colleges } \\
\hline Predicted to Enroll & 107 & 164 & 135 & 160 & 133 & 142 \\
\hline No. to Publics & $100(93 \%)$ & $154(94 \%)$ & $126(93 \%)$ & $146(91 \%)$ & $42(31 \%)$ & $129(91 \%)$ \\
\hline Tuition Price & $\$ 2,261$ & $\$ 1,832$ & $\$ 228$ & $\$ 1,994$ & $\$ 2,494$ & $\$ 3,343$ \\
\hline
\end{tabular}

See the notes on the following page. 
TABLE 7: Predicted College Investments under Different Aid Schemes - continued

\begin{tabular}{|c|c|c|c|c|c|c|}
\hline \multicolumn{7}{|c|}{ C. Low-Income Students (Family income below $\$ 20,000$ in 1991) } \\
\hline Total Enrollment & 915 & 904 & 912 & 898 & 906 & 864 \\
\hline \multicolumn{7}{|l|}{ Four-year Colleges } \\
\hline Predicted to Enroll & 542 & 500 & 529 & 497 & 536 & 446 \\
\hline No. to Publics & $434(80 \%)$ & $384(77 \%)$ & $417(79 \%)$ & $324(65 \%)$ & $354(66 \%)$ & $268(60 \%)$ \\
\hline Tuition Price & $\$ 4,004$ & $\$ 4,799$ & $\$ 4,455$ & $\$ 4,804$ & $\$ 4,471$ & $\$ 7,000$ \\
\hline Expenditures & $\$ 6,315$ & $\$ 5,764$ & $\$ 5,808$ & $\$ 5,699$ & $\$ 5,701$ & $\$ 6,069$ \\
\hline SAT percentile & 62.2 & 59.71 & 59.87 & 59.11 & 59.19 & 60.3 \\
\hline \multicolumn{7}{|l|}{ Two-year Colleges } \\
\hline Predicted to Enroll & 373 & 404 & 383 & 401 & 370 & 418 \\
\hline No. to Publics & $352(94 \%)$ & $379(94 \%)$ & $359(94 \%)$ & $363(91 \%)$ & $338(91 \%)$ & $381(91 \%)$ \\
\hline Tuition Price & $\$ 1,970$ & $\$ 2,902$ & $\$ 2,956$ & $\$ 2,884$ & $\$ 3,019$ & $\$ 3,806$ \\
\hline
\end{tabular}

Sources: NELS88 individual data and 1991-92 IPEDS college data.

Notes: Colleges were weighted by: (1) the relative odds of that person choosing that college (calculated from Table 2, specification 2), and (2) the individual likelihood of attendance (calculated from Table 3, specification 3). Figures are in 1992 dollars. Where applicable, the tuition price is adjusted for the loss of state appropriations per FTE student minus any voucher. The voucher value was calculated as the total state appropriations for nonspecialized colleges divided by the FTE number of students attending these colleges (for simulations 2 and 3, only students attending public colleges were counted). In the simulations in which the four-year voucher is twice as large as the two-year voucher (simulations 3 and 5), 70 percent of students are assumed to attend four-year schools. 